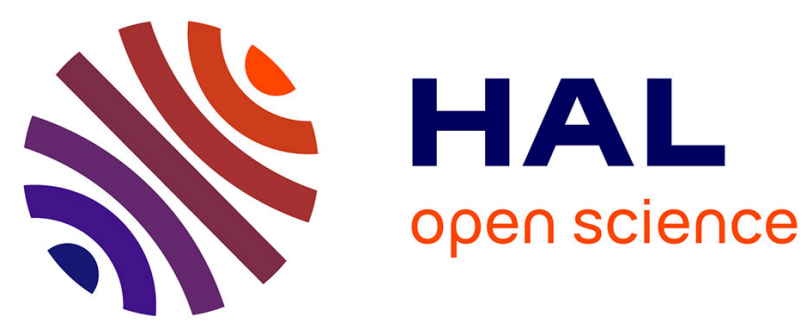

\title{
Focused Magmatism versus Amagmatic spreading along the ultraslow-spreading Southwest Indian Ridge. Evidence from TOBI side scan sonar imagery
}

Daniel Sauter, Véronique Mendel, Céline Rommevaux-Jestin, Lindsay M. Parson, Hiromi Fujimoto, Catherine Mével, Mathilde Cannat, Kensaku Tamaki

\section{To cite this version:}

Daniel Sauter, Véronique Mendel, Céline Rommevaux-Jestin, Lindsay M. Parson, Hiromi Fujimoto, et al.. Focused Magmatism versus Amagmatic spreading along the ultraslow-spreading Southwest Indian Ridge. Evidence from TOBI side scan sonar imagery. Geochemistry, Geophysics, Geosystems, 2004, 5, pp.20. 10.1029/2004GC000738 . hal-00104253

\section{HAL Id: hal-00104253 \\ https://hal.science/hal-00104253}

Submitted on 9 Jun 2017

HAL is a multi-disciplinary open access archive for the deposit and dissemination of scientific research documents, whether they are published or not. The documents may come from teaching and research institutions in France or abroad, or from public or private research centers.
L'archive ouverte pluridisciplinaire HAL, est destinée au dépôt et à la diffusion de documents scientifiques de niveau recherche, publiés ou non, émanant des établissements d'enseignement et de recherche français ou étrangers, des laboratoires publics ou privés. 


\section{Focused magmatism versus amagmatic spreading along the ultra-slow spreading Southwest Indian Ridge: Evidence from TOBI side scan sonar imagery}

\section{Daniel Sauter and Véronique Mendel}

Institut de Physique du Globe, CNRS-ULP UMR 7516, 5 rue René Descartes, 67084 Strasbourg, France

(daniel.sauter@eost.u-strasbg.fr; veronique.mendel@eost.u-strasbg.fr)

\section{Céline Rommevaux-Jestin}

Laboratoire de Géosciences Marines, CNRS UMR 7097, Université Pierre et Marie Curie/Institut de Physique du Globe, 4 Place Jussieu, 75252 Paris Cedex 05, France (rommevan@ipgp.jussieu.fr)

\section{Lindsay M. Parson}

Challenger Division for Seafloor Processes, Southampton Oceanography Centre, Empress Dock, Southampton SO14 3ZH,UK (lmp@soc.soton.ac.uk)

\section{Hiromi Fujimoto}

Research Center for the Prediction of Earthquakes and Volcanic Eruptions, Tohoku University Aobaku, Sendai, 9808578,Japan(fujimoto@aob.geophys.tohoku.ac.jp)

\section{Catherine Mével and Mathilde Cannat}

Laboratoire de Géosciences Marines, CNRS UMR 7097, Université Pierre et Marie Curie/Institut de Physique du Globe, 4 Place Jussieu, 75252 Paris Cedex 05, France (mevel@ipgp.jussieu.fr; cannat@ipgp.jussieu.fr)

\section{Kensaku Tamaki}

Ocean Research Institute, University of Tokyo, 1-15-1 Minamidai, Nakano-ku, Tokyo 164, Japan

(tamaki@ori.u-tokyo.ac.jp)

[1] The analysis of the Towed Ocean Bottom Instrument (TOBI) side scan sonar images along the Southwest Indian Ridge between $63^{\circ} 40^{\prime} \mathrm{E}$ and $65^{\circ} 40^{\prime} \mathrm{E}$ reveals strong focusing of magmatic activity and long amagmatic accretionary ridge segments. Fresh-looking volcanic terrains are observed at distinct locations along the axis separated by highly tectonized and sedimented terrains of an alongaxis extent as much as $82 \mathrm{~km}$. The largest tectonized section corresponds to a dramatically thin crust area with moderate magnetization anomalies. We suggest that seafloor spreading is mainly amagmatic in this tectonized section of the Southwest Indian Ridge with upper mantle rocks exposed at the seafloor. Amagmatic accretionary ridge segments of such dimensions are quite distinct from what is observed at the Mid-Atlantic Ridge but are also recognized at the Gakkel Ridge and may thus be characteristic of ultra-slow spreading ridges. The correlation between the distribution of fresh-looking volcanic terrains, the occurrence of shallow areas crowned by axial volcanic ridges, and high magnetization values suggests a shallow segmentation of the ridge mainly related to variation in the thickness and/or the intrinsic magnetization of the basaltic source layer. By contrast, strong along-axis variations of the gravity-derived crustal thickness are shrunken in length relative to this shallow segmentation of the ridge and occur only beneath the elevated segments. Adjacent to these elevated segments, small bathymetric swells with fresh-looking volcanic constructions do not correspond to thicker crust areas. This suggests a highly focused melt supply beneath the elevated segments which may feed volcanic constructions up to $60 \mathrm{~km}$ from the center of these segments by shallow lateral melt migration in the crust, probably through large dikes. Neither the ultra-slow spreading rate nor the ridge 
obliquity explains the variation of the magmatic vigor along the ridge. Mantle source heterogeneities together with lower mantle temperatures beneath the easternmost Southwest Indian Ridge could partly control its segmentation.

Components: 10,200 words, 9 figures.

Keywords: mid-ocean ridges; Southwest Indian Ridge; side scan sonar images; ridge segmentation; ultra-slow spreading.

Index Terms: 1550 Geomagnetism and Paleomagnetism: Spatial variations attributed to seafloor spreading (3005); 3035 Marine Geology and Geophysics: Midocean ridge processes; 3045 Marine Geology and Geophysics: Seafloor morphology and bottom photography.

Received 6 April 2004; Revised 12 July 2004; Accepted 5 August 2004; Published 26 October 2004.

Sauter, D., V. Mendel, C. Rommevaux-Jestin, L. M. Parson, H. Fujimoto, C. Mével, M. Cannat, and K. Tamaki (2004), Focused magmatism versus amagmatic spreading along the ultra-slow spreading Southwest Indian Ridge: Evidence from TOBI side scan sonar imagery, Geochem. Geophys. Geosyst., 5, Q10K09, doi:10.1029/2004GC000738.

Theme: Accretionary Processes Along the Ultra-Slow Spreading Southwest Indian Ridge Guest Editors: Catherine Mevel and Daniel Sauter

\section{Introduction}

[2] The spreading rate of the Southwest Indian Ridge (SWIR) is almost constant (about 14$15 \mathrm{~km} / \mathrm{m}$.y.) from the Andrew Bain fracture zone (FZ; $\left.32^{\circ} \mathrm{E}\right)$ to the Rodrigues Triple Junction $\left(70^{\circ} \mathrm{E}\right.$; RTJ) [DeMets et al., 1990; Patriat et al., 1997]. However, marked changes of segmentation style and mean axial depth occur across the Gallieni and Melville FZs (at $52^{\circ} 15^{\prime} \mathrm{E}$ and $60^{\circ} 45^{\prime} \mathrm{E}$, respectively; Figure 1) [Cannat et al., 1999; Sauter et al., 2001]. Mean axial depths increase eastward from $3090 \mathrm{~m}$ west of the Gallieni FZ to $4330 \mathrm{~m}$ between the Gallieni and the Melville FZs. They reach $4730 \mathrm{~m}$ in the deepest part of the ridge, between the Melville FZ and $69^{\circ} \mathrm{E}$ close to the RTJ. This large scale variation of axial depths suggests that the regional density structure of the axial region also varies, the deepest ridge section to the east of the Melville FZ being underlain by thinner crust and/or colder mantle. Differences in mantle temperature and in melt thickness between these regions have been estimated to be $\sim 100^{\circ} \mathrm{C}$ and $\sim 4 \mathrm{~km}$ respectively (assuming isostatic compensation of the ridge topography at the regional scale, a compensation depth of $200 \mathrm{~km}$, and a reference depth of $3500 \mathrm{~m}$ for a crustal thickness of $5.5 \mathrm{~km}$ [Cannat et al., 1999]). Anomalously thin crust in the Melville FZ - RTJ region is also indicated by seismic data [Muller et al., 1999]. The composition of basalts to the east of the Melville FZ reveals that the mantle in that area cannot be described by a low-degree melting of a typical mid-ocean-ridge source mantle but has a complex history involving extensive early melting events and interaction with partial melts of a more fertile source [Meyzen et al., 2003]. However, the along-axis variation of geochemical indicators of the extent of partial melting (such as the $\mathrm{Na}_{8.0}$ content of basaltic glasses) between $49^{\circ} \mathrm{E}$ and $70^{\circ} \mathrm{E}$ shows that the partial melting is higher for the basalts to the west of the Gallieni FZ and decreases eastward [Meyzen et al., 2003]. Very low-degree of melting of abyssal peridotites are also estimated in the $61-64^{\circ} \mathrm{E}$ region of the SWIR from the $\mathrm{Cr} /(\mathrm{Cr}+\mathrm{Al})$ ratio in spinels [Seyler et al., 2003]. These peridotites display strong heterogeneities and inconsistencies in modal and mineral compositions at local and regional scales. The geochemistry of both the basalts and the peridotites to the east of the Melville FZ argues for a strongly heterogeneous mantle source composition there [Meyzen et al., 2003; Seyler et al., 2003]. A positive anomaly of S-wave velocities is consistent with a colder and thus denser mantle beneath the easternmost section of the SWIR [Debayle and Lévêque, 1997].

[3] The short-scale segmentation pattern also varies markedly on either side of the Melville FZ. Between the Gallieni and the Melville FZs, $\sim 50 \mathrm{~km}$-long segments occur regularly and the segmentation looks similar to that of the Mid Atlantic Ridge (MAR) despite the occurrence of much larger non-transform discontinuities [Sauter et al., 2001]. By contrast, the segmentation pattern is highly variable east of the Melville FZ and is 

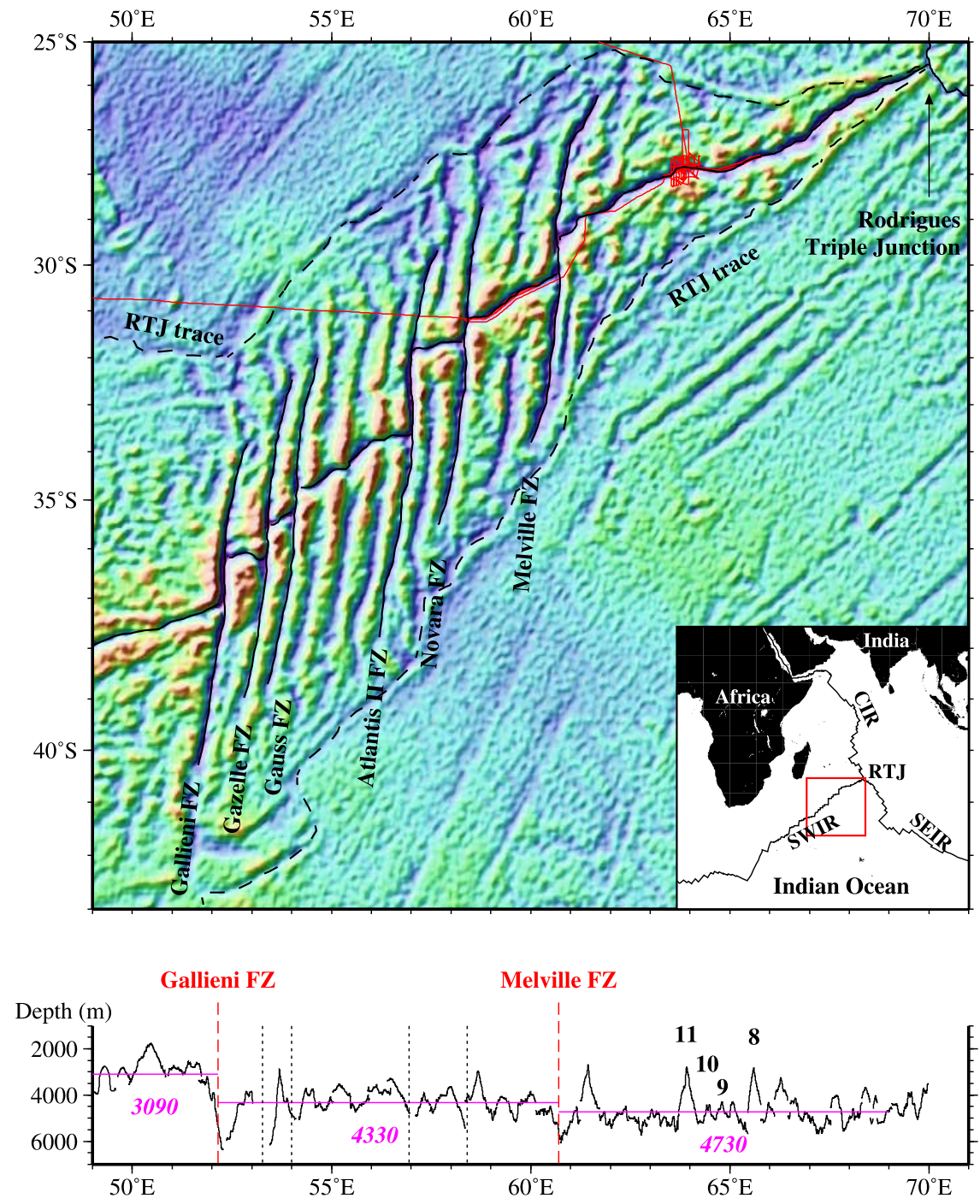

Figure 1. (top) Structural map and (bottom) along-axis bathymetric profile of the Southwest Indian Ridge (SWIR) between $49^{\circ} \mathrm{E}$ and $70^{\circ} \mathrm{E}$. On the structural map, thick black lines indicate the fractures zones, the triple junction traces, and the SWIR axis, which are interpreted from the free air gravity anomalies (shown in background) derived from satellite sea-surface altimeter measurements [Smith and Sandwell, 1995]. Red lines show tracks of the FUJI cruise. SEIR, Southeast Indian Ridge; CIR, Central Indian Ridge; RTJ, Rodrigues Triple Junction. On the bathymetric profile, numbers indicate the segments cited in the text and in other figures following the nomenclature of Cannat et al. [1999]. The magenta lines show the mean axial depth to the west of the Gallieni FZ, between the Gallieni and Melville FZs, and between the Melville FZ and $69^{\circ} \mathrm{E}$ close to the RTJ.

marked by three elevated segments where the rift valley floor shallows by more than $2000 \mathrm{~m}$ [Mendel et al., 1997]. The absence of off-axis traces of long-lived axial discontinuities to the east of the Melville FZ indicates that this ridge segmentation is not stable. The elevated segments correspond to large volcanic constructions that fill the axial valley at segment centers [Cannat et al., 1999]. They are significantly larger than the volcanic edifices that have been described at the MAR [Smith and Cann, 1999], but could be similar to volcanic features described at the ultra-slow spreading Gakkel and Knipovitch Ridges in the Artic [Okino et al., 2002; Cochran et al., 2003; Dick et al., 2003; Michael et al., 2003]. Occurrence of very large volcanic constructions in the easternmost section of the SWIR are not expected by melting models and raise the issues of how the generation and transport of the magma along ultraslow spreading ridges is achieved. Melting models predict indeed that conductive cooling of the lithosphere from above becomes significant as spreading rates diminish to $<20 \mathrm{~mm} / \mathrm{yr}^{-1}$ [Reid and Jackson, 1981; Bown and White, 1994] causing 
a
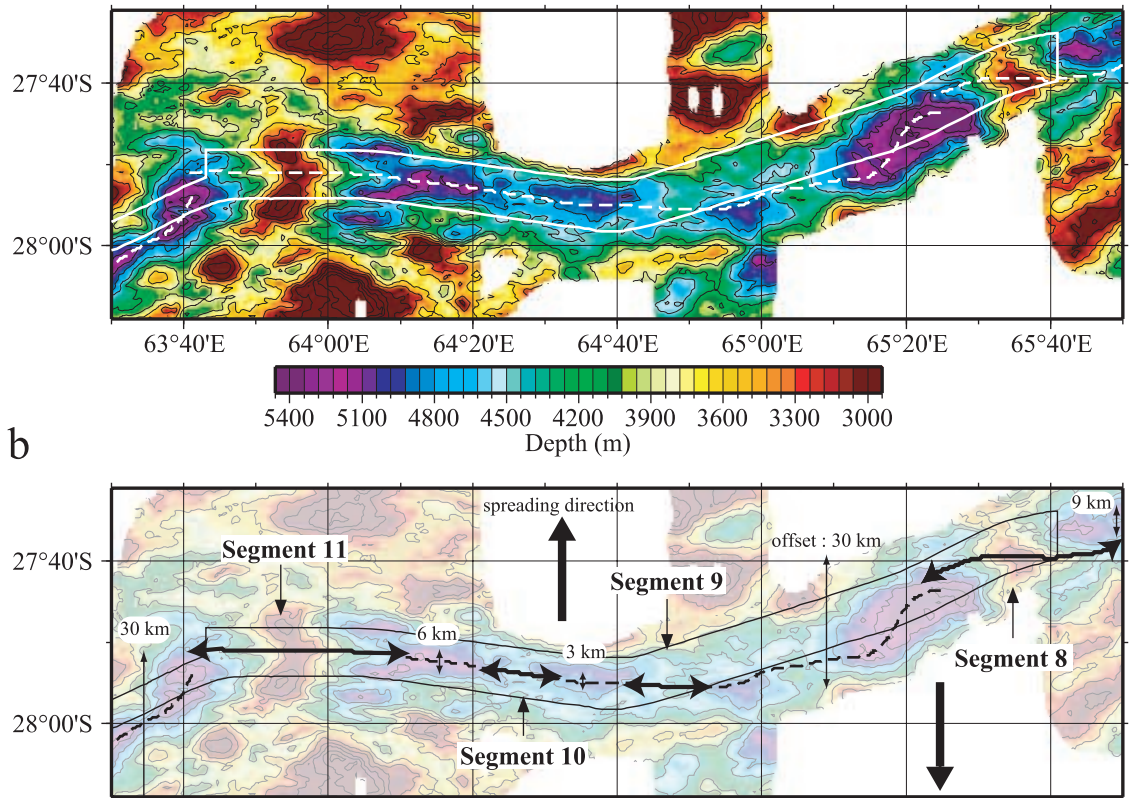

$63^{\circ} 40^{\prime} \mathrm{E}$

$64^{\circ} 00^{\prime} \mathrm{E} \quad 64^{\circ} 20^{\prime} \mathrm{E}$

$64^{\circ} 40^{\prime} \mathrm{E}$

$65^{\circ} 20^{\prime} \mathrm{E}$

$65^{\circ} 40^{\prime} \mathrm{E}$

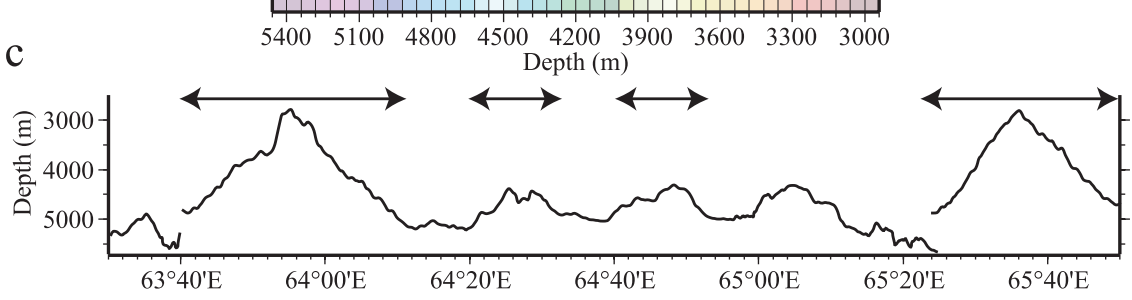

Figure 2. (a) Bathymetry, (b) ridge segmentation, and (c) along-axis depth profile of the Southwest Indian Ridge between $63^{\circ} 30^{\prime} \mathrm{E}$ and $65^{\circ} 50^{\prime} \mathrm{E}$. (a) The dashed line indicates the axis drawn by picking the crest of axial volcanic ridges wherever these are present and the deepest point of the axial valley in the absence of intrarift ridges. Thick white lines bound the TOBI imagery. Color interval is every $60 \mathrm{~m}$. Contour interval is every $300 \mathrm{~m}$. (b) EW trending black lines with arrowheads indicate the extent of each segments. The dashed black line corresponds to the axis outside these segments. NS trending thin black lines with arrowheads indicate the offsets between the segments. Spreading direction is NS in the survey area. (c) Arrows indicate the extent of the segments.

cessation of decompression melting at greater depth, lower overall extents of melting and thus greater depth of crystallization than at faster spreading ridges [Michael and Cornell, 1998] leading to little extrusive volcanism.

[4] In this paper, we present high-resolution side scan sonar data along the easternmost part of the SWIR between $63^{\circ} 40^{\prime} \mathrm{E}$ and $65^{\circ} 40^{\prime} \mathrm{E}$ (Figure 1), to document the type and distribution of the axial volcanism and the orientations of the faults along such two elevated segments and the intervening ridge section. We show that fresh-looking volcanic constructions occur on the two elevated segments and that no fresh volcanism occurs along an intensely faulted $82 \mathrm{~km}$-long ridge section between them. This distribution is then compared to the magnetic structure of the ridge obtained by calcu- lating the magnetization solution in the survey area and to the along-axis variation of the gravity-derived crustal thickness previously published by Cannat et al. [2003]. We then discuss the magmatic delivery systems to the volcanic constructions and suggest that the magma supply may be highly focused beneath the elevated segments. Furthermore, we suggest that seafloor spreading is mainly amagmatic in the tectonized section of the survey area with upper mantle rocks exposed at the seafloor.

\section{Data Collection and Processing}

[5] The Towed Ocean Bottom Instrument (TOBI) data [Flewellen et al., 1993] were acquired during the French-UK-Japanese InterRidge (FUJI) cruise on board the R/V Marion Dufresne in October 
$\mathbf{a}$

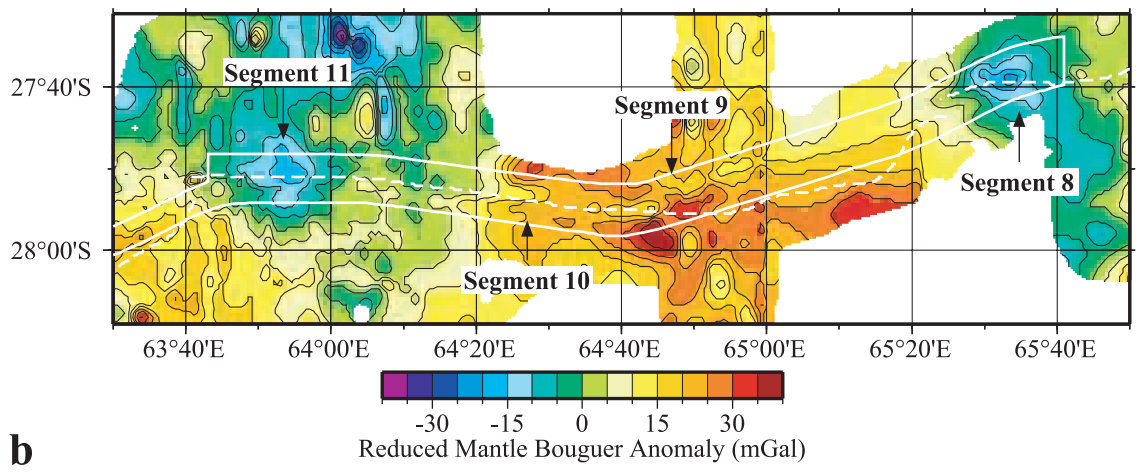
Reduced Mantle Bouguer Anomaly (mGal)
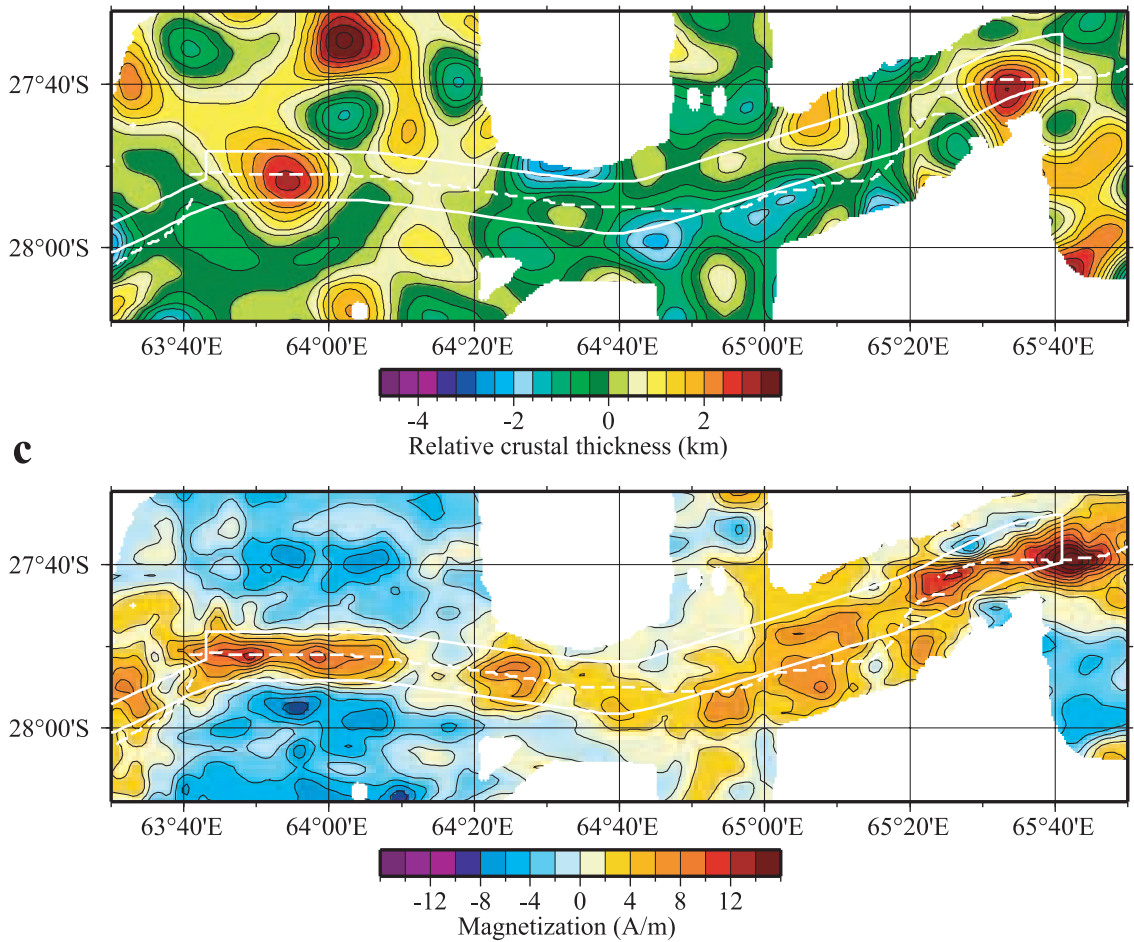

Figure 3. (a) Residual Mantle Bouguer Anomaly (RMBA) map, (b) relative gravity-derived crustal thickness after Cannat et al. [2003], and (c) magnetization map of the Southwest Indian Ridge between $63^{\circ} 30^{\prime} \mathrm{E}$ and $65^{\circ} 50^{\prime} \mathrm{E}$. The dashed line indicates the axis, and the thick white lines bound the TOBI imagery as in Figure 2. (a) Color and contour intervals of the residual Mantle Bouguer Anomaly are every $5 \mathrm{mGal}$. (b) Color and contour intervals of the relative crustal thickness map are every $400 \mathrm{~m}$. (c) Color and contour intervals of the magnetization map are every $2 \mathrm{~A} / \mathrm{m}$.

1997 [Tamaki et al., 1998]. The survey was designed to cover two elevated segments centered at $63^{\circ} 55^{\prime} \mathrm{E}$ and $65^{\circ} 36^{\prime} \mathrm{E}$, respectively, and the linking spreading axis section (Figure 2). These segments correspond to segments \#8 and \#11 using the numbering system of Cannat et al. [1999]. The TOBI side scan sonar images of the SWIR axial valley floor were acquired along two parallel tracks separated by approximately $5 \mathrm{~km}$ resulting in $100 \%$ insonification of the axial floor over a region approximately $200 \mathrm{~km}$ long and $11 \mathrm{~km}$ wide between $63^{\circ} 40^{\prime} \mathrm{E}$ and $65^{\circ} 40^{\prime} \mathrm{E}$. The TOBI images cover almost the entire inner valley floor at the segment centers but the walls of the axial valley (up to $15 \mathrm{~km}$ wide) were less continuously ensonified. TOBI was operated at altitudes of 250$700 \mathrm{~m}$ above the seafloor with a tow speed of about 2 knots. The final across-track horizontal resolution of the data is about $6 \mathrm{~m}$ while along-track resolution varies up to $50 \mathrm{~m}$ at far range.

[6] We calculated the magnetization solution of the TOBI survey area (Figure 3c) using the data collected during the Capsing cruise in 1993 [Patriat et al., 1997], the FUJI cruise in 1997 [Tamaki et al., 1998], the INDOYO cruise in 1998 [Fujimoto et al., 
1999] and the SWIR6165 cruise in 2003 [Cannat et al., 2004]. A three-dimensional inversion for crustal magnetization was performed using the Fourier technique of Parker and Huestis [1974] and extended for grid analysis by Macdonald et al. [1980] to account for the distorting effects of seafloor topography and skewness. A source layer of constant thickness $(0.5 \mathrm{~km})$ and an upper boundary defined by the bathymetry were assumed. To ensure convergence during the inversion, we employed cosine tapered band-pass filters with long- and short-wavelength cutoffs of 400 and $3.5 \mathrm{~km}$. As the magnetization solution is more or less balanced over the Brunhes/Matuyama reversal, no annihilator has been added to this solution.

[7] The crustal thickness variation map of Cannat et al. [2003] (Figure 3b) is deduced from residual gravity anomaly following Rommevaux et al. [1994]. The effect of a constant thickness $(3 \mathrm{~km})$, constant density $\left(2700 \mathrm{~kg} / \mathrm{m}^{3}\right)$ crust was removed from Free Air Anomaly data to obtain Mantle Bouguer Anomaly (MBA) values. The residual MBA (RMBA) values (Figure 3a) were then obtained by removing the gravity effect of cooling of the plates with age using the poles and rates of plate motion of Patriat and Segoufin [1988]. These residual anomalies were inverted to estimate the crustal thickness (Figure 3b) following the method of Kuo and Forsyth [1988] which assumes that gravity anomalies only reflect crustal thickness variations. This method involves a downward continuation of RMBA to a constant depth below sea level, corresponding to the inferred average Moho depth. The best fit between gravity-derived crustal thickness estimates and seismic crustal thicknesses determined along the $100 \mathrm{~km}$-long CAM116 profile [Muller et al., 1999] was obtained by Cannat et al. [2003] for gravity models calculated with a reference crustal thickness of $3 \mathrm{~km}$, and a downward continuation depth of $7 \mathrm{~km}$ (a water depth of $4 \mathrm{~km}$ and $3 \mathrm{~km}$ of crust). To avoid instabilities inherent to downward continuation of short wavelengths anomalies, a filter is applied which cosine tapers the RMBA signal with wavelengths between 35 and $25 \mathrm{~km}$, and cuts off the RMBA signal with wavelengths $<25 \mathrm{~km}$ (corresponding to sources located at depths less than the downward continuation depth).

\section{Ridge Segmentation in the Survey Area}

[8] The most striking features in the bathymetric map of the survey area are the two segments \#8 and \#11 which are shallowing up to a $2800 \mathrm{~m}$ depth (Figure 2a). With an along-axis relief up to $2600 \mathrm{~m}$, these elevated segments have a steeper slope than typical MAR segments (Figure 2c) [Mendel et al., 1997]. They correspond to 4.5$5 \mathrm{~km}$ thicker crust areas relative to the thinnest crust area located at about $65^{\circ} \mathrm{E}$ [Cannat et al., 2003] (Figure 3b). Large and oblique nontransform discontinuities with offsets of $30 \mathrm{~km}$ bound segments $\# 8$ and \#11 toward the west whereas to the east, minor offsets (of $9 \mathrm{~km}$ and $6 \mathrm{~km}$, respectively) do not affect the overall trend of the axis (Figure 2b). The axis therefore strikes subperpendicular to the spreading direction $\left(\mathrm{N} 0^{\circ} \mathrm{E}\right)$ at segment \#11 and in the western half of the survey area. It becomes oblique $\left(\mathrm{N} 60-65^{\circ} \mathrm{E}\right)$ in the eastern part with an en echelon setting of the E-W trending axial volcanic ridge (AVR) of segment \#8 (Figure 2). The AVRs crowning the elevated segments $\# 8$ and $\# 11$ are $40-50 \mathrm{~km}$ long. Hightemperature sulfide inactive chimneys as well as hydrothermal mounds have been observed at the center of segment \#11 [Münch et al., 2001] where the axial valley almost disappears. Segments \#9 and \#10 were identified by Mendel et al. [1997] on the basis of the occurrence of low-amplitude bathymetric swells (relief $<600 \mathrm{~m}$ ) crowned by small ridges (5 km-long and $300 \mathrm{~m}$ high) although these segments did not correspond to marked negative mantle Bouguer anomalies [RommevauxJestin et al., 1997] (Figure 3a). Another small bathymetric swell is located at $65^{\circ} 05^{\prime} \mathrm{E}$ (Figure 2) but was not identified as a segment by Mendel et al. [1997] due to incomplete bathymetric coverage of the axial valley before 1997.

\section{Results}

\subsection{Acoustic Facies at the SWIR}

[9] The amplitude of the TOBI sonar signal depends mainly on the angle of incidence, the acoustic impedance contrast between the seawater and seafloor, and the seafloor roughness [e.g., Blondel and Murton, 1997]. A high degree of roughness produces a greater return for the same acoustic impedance. Variations of seafloor roughness in the axial valley allow us to distinguish two types of volcanic texture on the TOBI imagery: smooth surfaces and hummocky terrains (Figures 4 and $5 \mathrm{a}-5 \mathrm{e}$ ). The hummocky texture consists of large conglomerations of subcircular mounds, individually with $<500 \mathrm{~m}$ diameters (Figures 5a-5e) which can be most readily attributed to individual pillow lava flows at the 


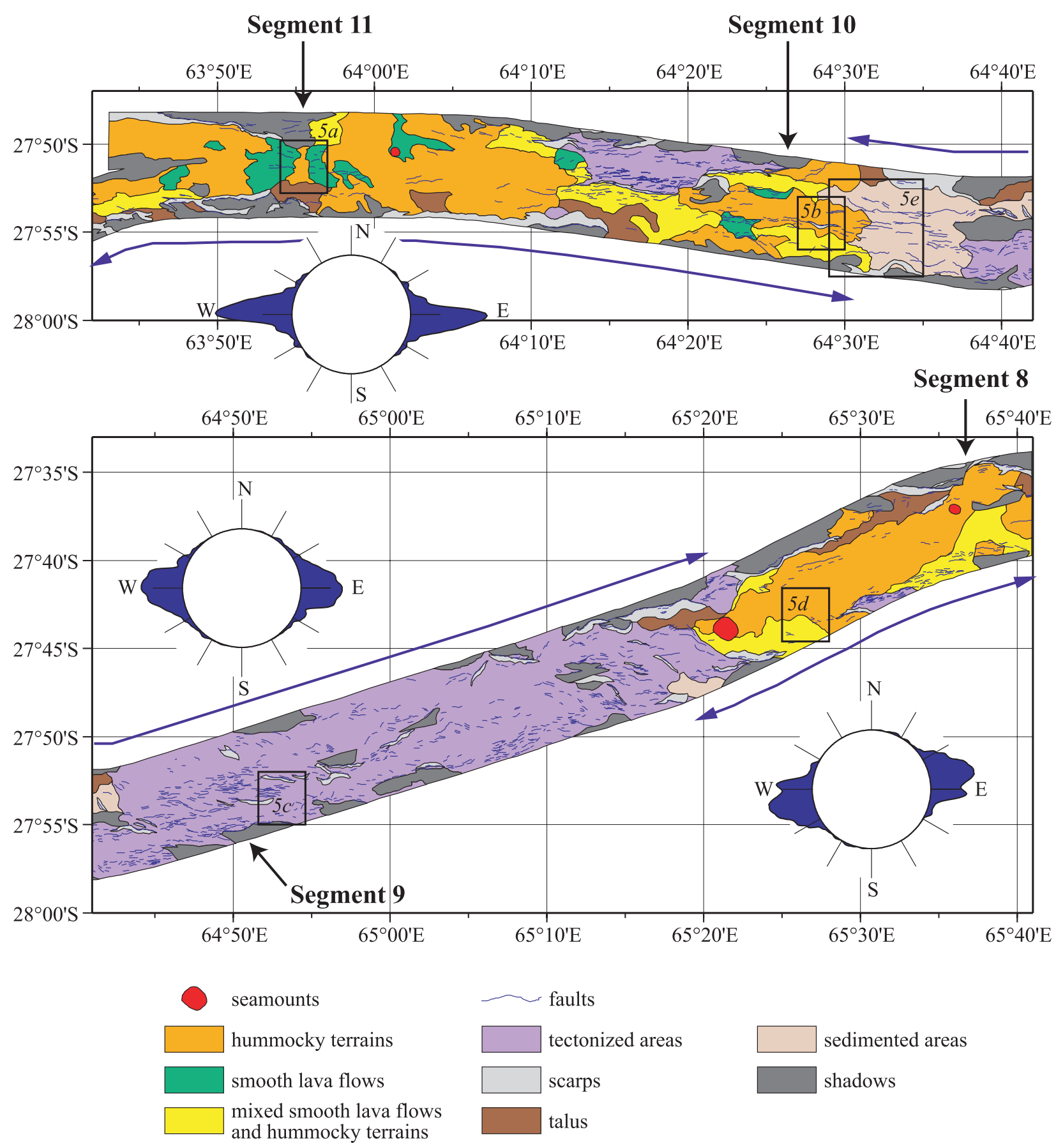

Figure 4. Map of the volcanic textures and tectonized areas identified on the side scan sonar images. Tectonized areas and sedimented areas are indicated where very strong faulting or a thick sediment cover prevents the identification of a volcanic texture. The identification of a volcanic texture does not preclude the occurrence of faults. Orientation distributions for the faults are shown for the ridge sections shown by the blue double-headed arrows. These distributions have been computed by binning the data with a continuous weighting function with a $5^{\circ}$ full width and with each value weighted by the fault length following Mitchell et al. [2000]. Small squares indicate the locations of Figures 5a, 5b, 5c, 5d, and 5e.

MAR [Lawson et al., 1996]. This type of volcanic edifice is the most abundant whereas flattopped seamounts are rare in the axial valley, as to the west of the Melville FZ [Sauter et al.,
2002] (Figure 4). In contrast to the hummocky terrains, smooth-textured regions comprise relatively flat and homogeneous backscattering areas (Figures $5 \mathrm{a}-5 \mathrm{e}$ ) which have been tentatively 
a. Smooth lava flow surrounding hummocks

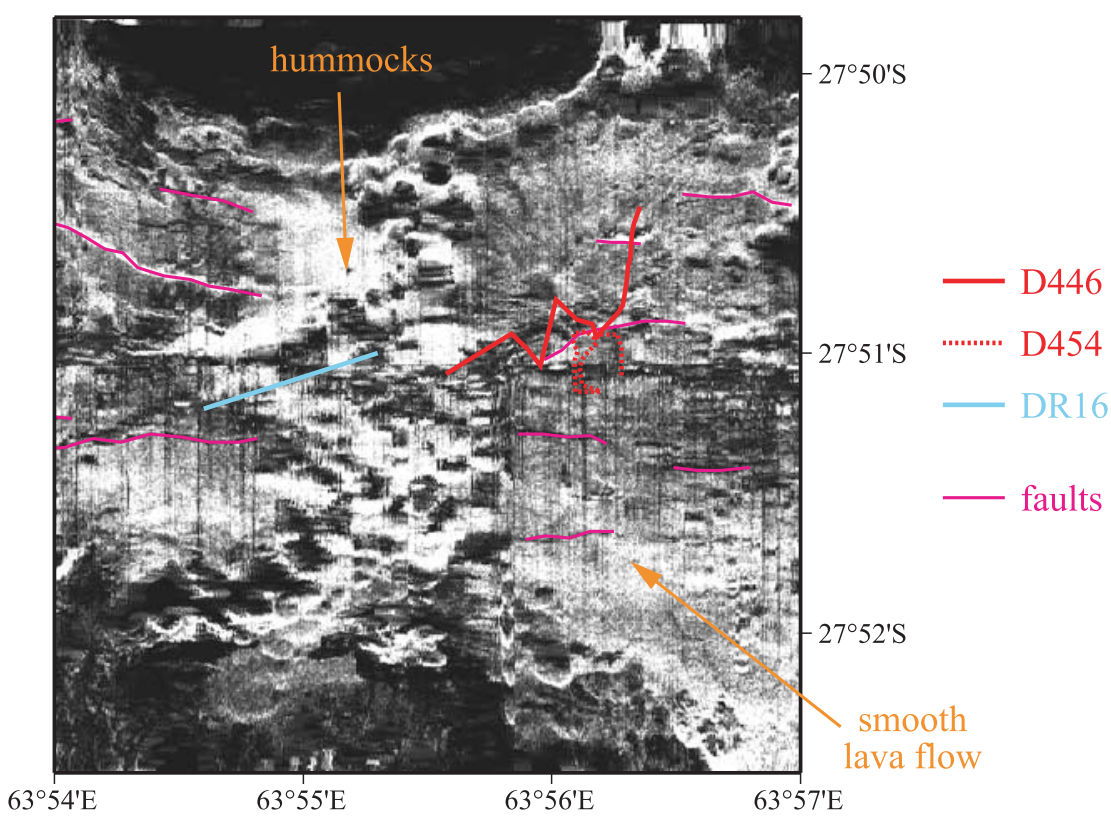

b. Fresh-looking hummocky terrain

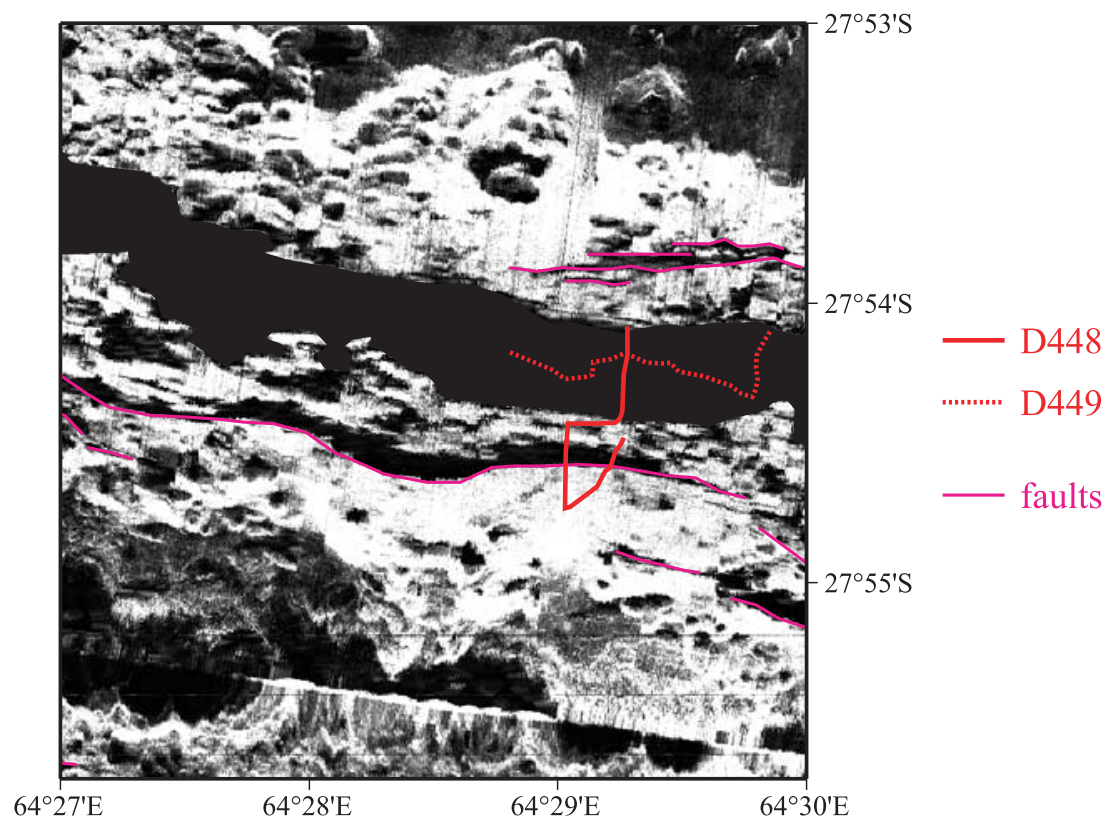

Figure 5. Different terrains identified from the TOBI side scan sonar images of the SWIR between $63^{\circ} 30^{\prime} \mathrm{E}$ and $65^{\circ} 50^{\prime} \mathrm{E}$. Locations of the different types of texture are given in Figure 4. Magenta lines indicate faults. (a) Smooth lava flows surrounding hummocks located at segment \#11 center. Red lines indicate dive tracks \#446 and \#454 of the INDOYO cruise [Fujimoto et al., 1999]; the blue line indicates dredge \#16 of the EDUL cruise [Mével and EDUL Shipboard Scientific Party, 1997]. (b) Fresh-looking hummocky terrain at the eastern axial volcanic ridge of segment \#10. Red lines indicate dive tracks \#448 and \#449 of the INDOYO cruise [Fujimoto et al., 1999]. (c) Sedimented and strongly tectonized area between segments \#9 and \#8. (d) Contact between partly sedimented, hummocky textured and weakly faulted smooth lava flows to the south and a fresh-looking hummocky area to the north on the axial volcanic ridge of segment \#8. (e) Contrast between fresh-looking hummocks at the eastern end of segment \#10 and highly sedimented terrain to the east. 
Geochemistry

c.

Tectonized area

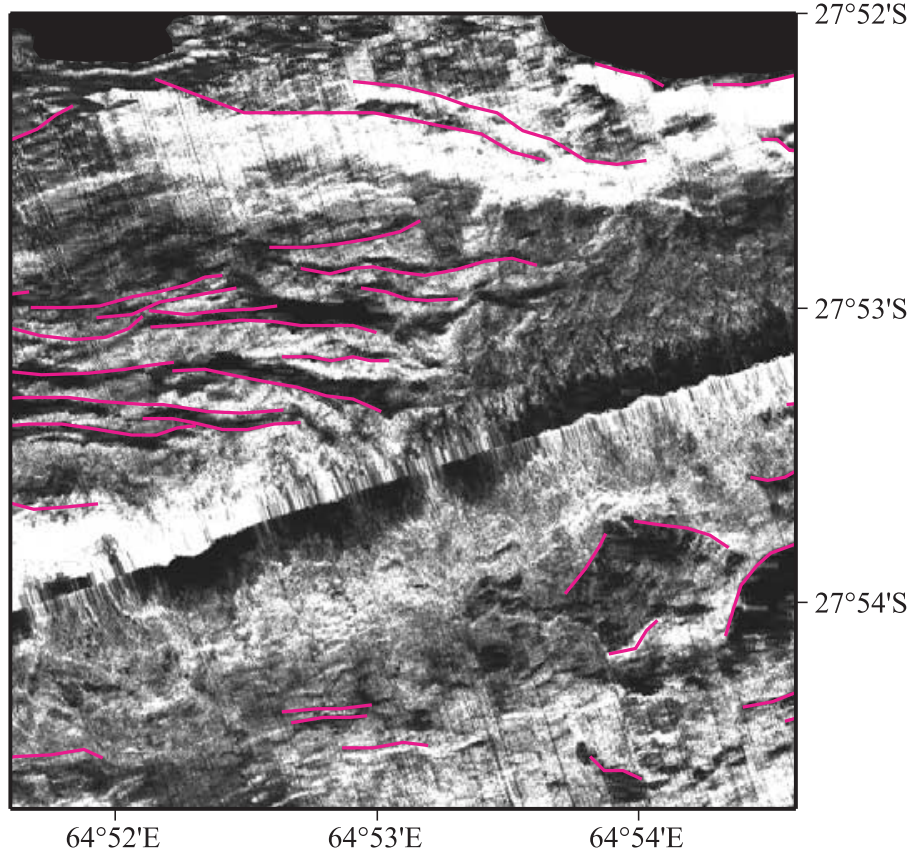

d. Contact between sedimented smooth lava flows and a fresh-looking hummocky terrain

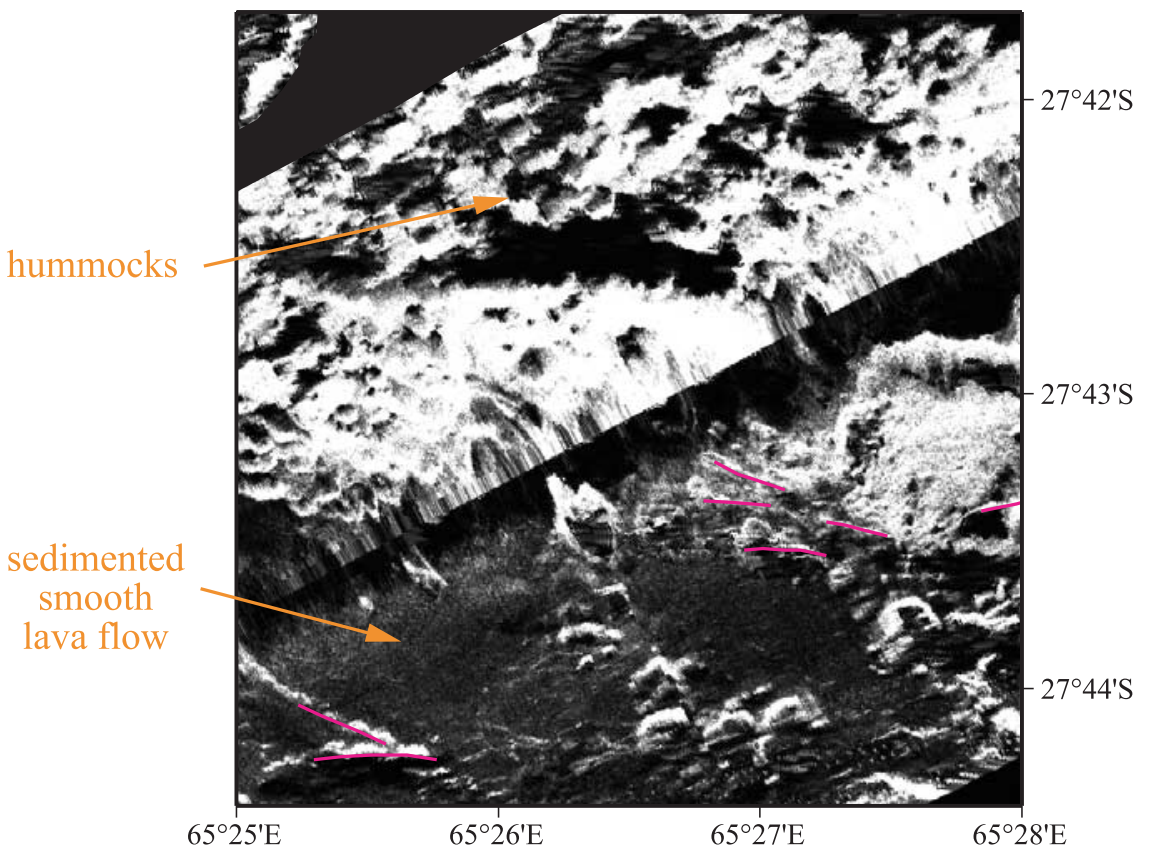

Figure 5. (continued)

interpreted as smooth lava flow surfaces or lava ponds [e.g., Sauter et al., 2002]. Side scan sonar acoustic textures are not helpful in determining between fresh pillow mounds and slightly deformed pillow constructs. By contrast, even mi- nor amounts of deformation affecting flat lying sheet flows, or lava lake extrusives, are readily imaged with side scan sonars as pervasive linear faulting patterns. In some areas of the axial zone, TOBI images revealed a very intense faulting 


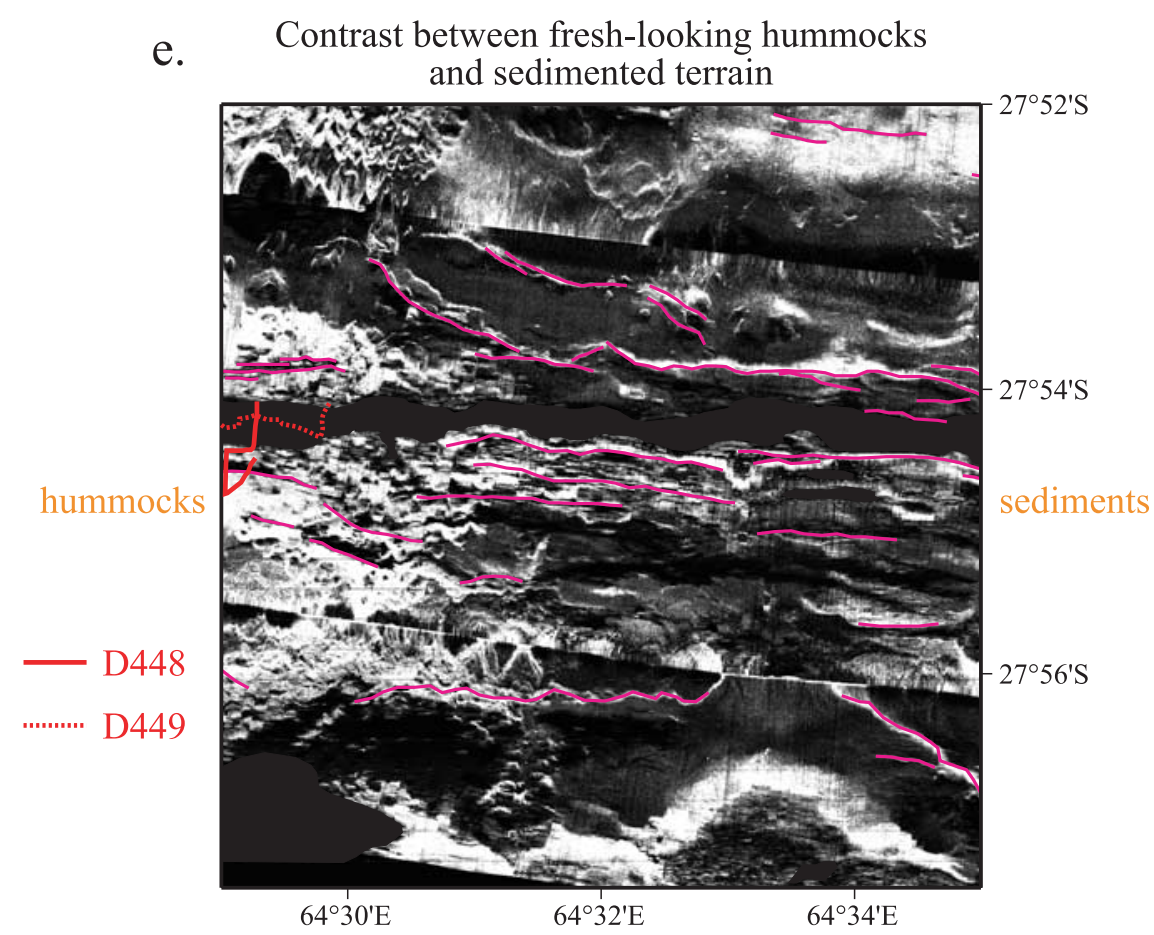

Figure 5. (continued)

pattern that prevented us from identifying the primary volcanic texture, if any (Figure $5 \mathrm{c}$ ). The mapping of these faults (Figure 4) was used to analyze the variation of the fabric orientations along the axis. Sediment causes a lower amplitude return because of acoustic penetration and attenuation in the subsurface. A 2-5 m thick cover may attenuate the backscatter by more than $20 \mathrm{~dB}$ [Mitchell, 1993]. We classified areas as sedimented hummocky terrains or smooth lava flows where we could recognize these volcanic textures with strongly reduced backscatter amplitudes probably caused by draping of sediments (Figure 5d). However, in a few areas with very low uniform backscatter amplitudes and smooth texture, probably caused by draping and ponding of sediments especially in segment discontinuities, no volcanic texture was observed leading to the simple identification of these areas as sedimented areas (Figure 5e). By contrast we refer to more recent or fresh volcanic areas for strongly backscattering regions where no fault or sediment cover is observed.

\subsection{Submersible Dives and Dredges}

[10] Groundtruthing in the survey area was possible with a small number of dredges (Figure 6) conducted during the EDUL cruise [Mével et al.,
1997] and 5 manned submersible dives during the INDOYO cruise (Shinkai 6500 dives \#446, \#447, \#448, \#449, \#454) [Fujimoto and MODE'98 Leg3 Shipboard Scientific Party, 1998]. Out of 9 dredge stations occupied in the survey area during the EDUL cruise, only one targeted both the smooth acoustic facies and hummocky terrains (dredge \#16; Figures 5a and 6). This dredge, like dredge \#12 on the flat-topped seamount at $65^{\circ} 21^{\prime} \mathrm{E}$, recovered both fresh, glassy flow surfaces and pillow lavas [Mével and EDUL Shipboard Scientific Party, 1997]. Two other dredge stations (\#19 and \#11) targeted hummocky terrains and recovered mainly pillow lavas [Mével and EDUL Shipboard Scientific Party, 1997]. Dredge \#20 falls in an area without side scan coverage. The results of dives \#446 and \#454 on the segment \#11 [Münch et al., 2001] shows that there is overall good agreement between hummocky terrain and pillow mound topography and between smooth texture and smooth lava surfaces (Figure 7). However, some isolated pillow lavas were found within sheet flow units and are apparently overlain by them. These pillow units are barely recognizable on the side scan sonar image because of their small size and low roughness (Figures 5a). Two dives (\#448 and \#449) were carried out on the eastern AVR of segment \#10 where hummocky terrain has been recognized on the side scan sonar image (Figure 5b). The domi- 


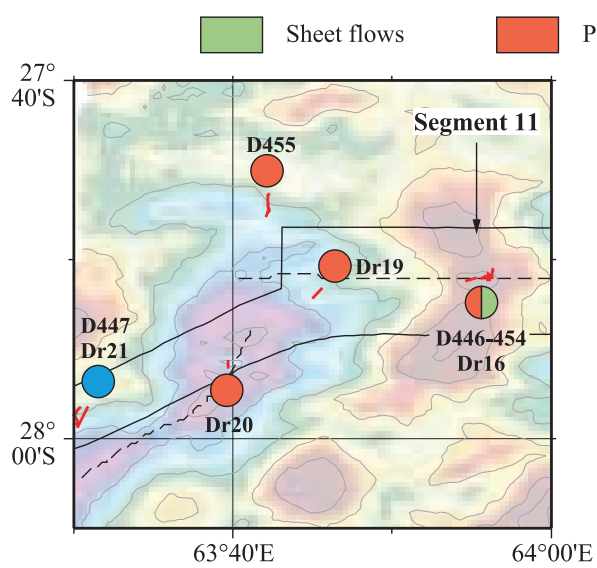

Pillow basalts $\quad \square$ Peridotites
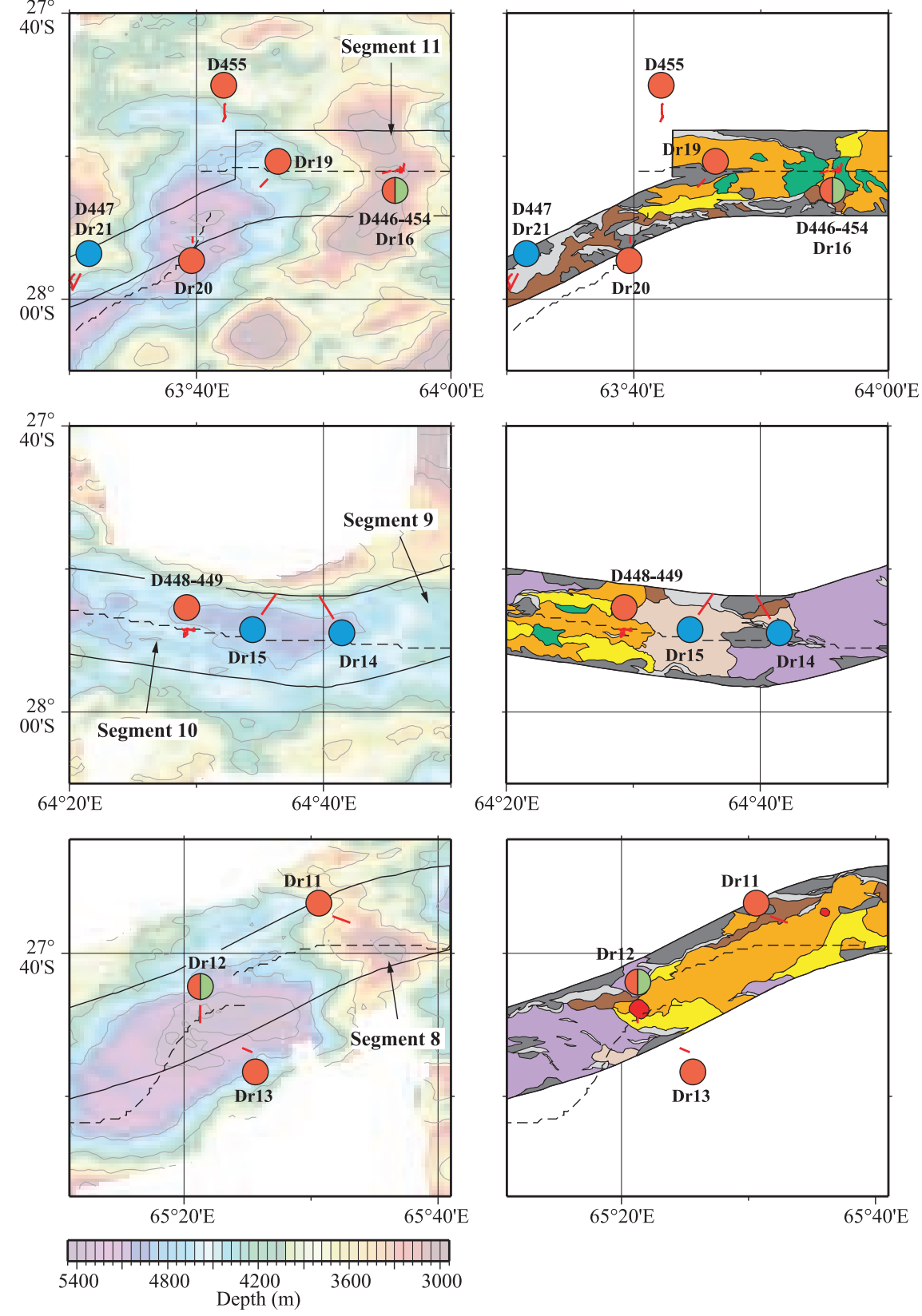

Figure 6. Dominant lithologies found in dredges performed during the EDUL cruise [Mével et al., 1997] and observed during 5 manned submersible dives of the Shinkai 6500 (dives \#446, \#447, \#448, \#449, \#454 of the INDOYO cruise) [Fujimoto and MODE'98 Leg3 Shipboard Scientific Party, 1998]. Bathymetric data are shown in background. Red lines indicate the locations of these dredges and dives. The dashed line indicates the axis as in Figure 2. A continuous black line bounds the TOBI imagery.

nant lithology observed during these two dives was bulbous pillow lavas, tubes and disaggregated pillow fragments (Figure 6). We thus confirm that hummocky terrain may be interpreted as pillow mound topography and that the smooth-textured and homogeneous areas may be generally associ- ated with smooth lava surfaces although some small-scale pillow mounds may also be present. Serpentinized peridotites have been dredged midway between the two elevated segments and in the deep non-transform discontinuity to the east of segment 11 (dredge \#14, \#15 and \#21, Figure 6). 


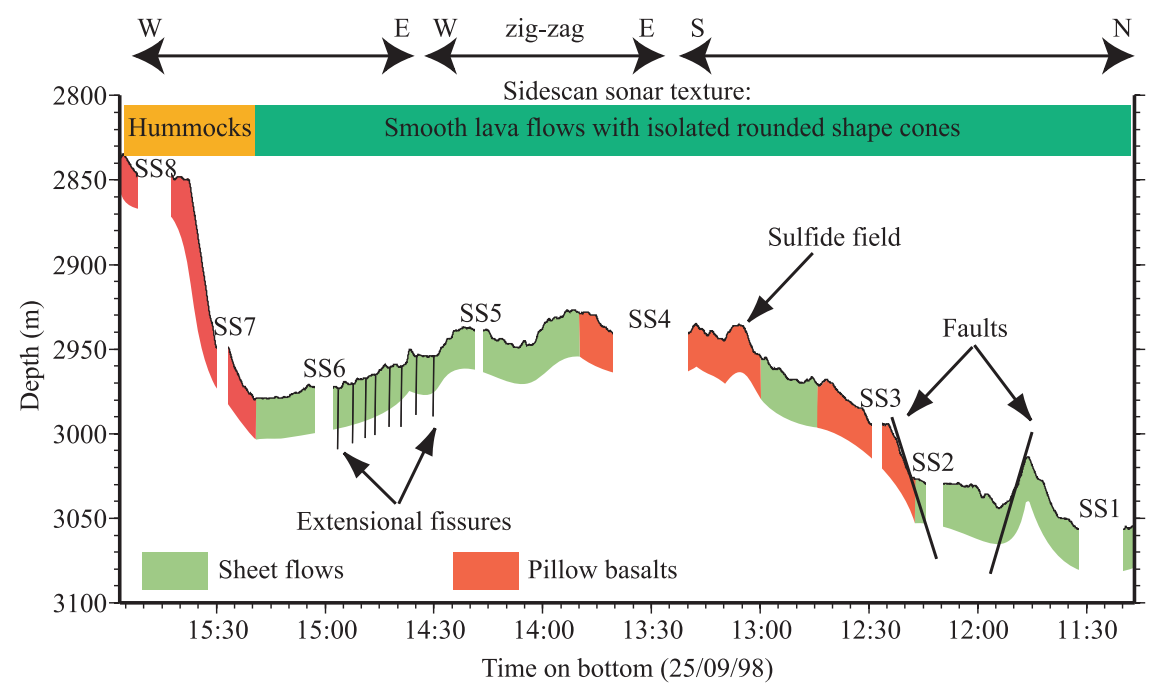

Figure 7. Depth profile of dive \#446 with geological interpretation and station positions (SS1-SS8) and the corresponding texture on the side scan sonar image (see Figures 5a and 6 for the location of the dive).

These dredge stations were occupied on the axial valley walls which correspond to large scarps in the TOBI images.

\subsection{Geological Mapping}

[11] The axial valley inner floor of segment \#11 is mostly composed of fresh-looking hummocky terrain from about $63^{\circ} 42^{\prime} \mathrm{E}$ to $64^{\circ} 12^{\prime} \mathrm{E}$ (Figures 4 and 8 ). Smooth lava flows are observed in the deeper areas at the base of the AVR and on each side of the summit of segment \#11 corresponding to a pillow mound (Figure 5a). Sharp boundaries between large areas of hummocks and smooth lava surfaces (Figure 5a) indicate different ages for the corresponding volcanic units. Moreover, the lesser degree of faulting affecting the hummocks at the segment center than the surrounding smooth lava surfaces suggests that the pillow lavas at the summit of the segment are the most recent (Figure 4). Numerous, evenly spaced, small extensional fissures with the same EW orientation have also been observed in a sheet flow unit on the flanks of the summit of segment \#11 during dive \#446 of the INDOYO cruise (Figure 7). A pillow lavas unit overlain by a sheet flow unit was observed during the same dive. These spatial and temporal relationships between the different types of volcanism with different degrees of faulting suggest that the AVR has been built, at least recently, by successive episodes of sheet flows and pillow lava emplacements. Segment \#11 is only slightly tectonized and the few faults are mostly EW with orientations ranging from $\mathrm{N} 80^{\circ} \mathrm{E}$ to $\mathrm{N} 100^{\circ} \mathrm{E}$ (Figure 4). Fresh-looking volcanic textures along the AVR give way to a highly deformed and partly sedimented area in the deepest part of the axial valley centered at $64^{\circ} 18^{\prime} \mathrm{E}$ midway between segment \#11 and segment \#10 (Figures 4 and 8). The density of faults is high (spacing $<500 \mathrm{~m}$ ). These faults have the same overall E-W orientation as in segment \#11. A band of fresh-looking volcanic constructions is still observed in this area at the foot of the southern valley wall. Texture of the axial valley floor is again dominated by hummocks at segment $\# 10$ between $64^{\circ} 20^{\prime} \mathrm{E}$ and $64^{\circ} 31^{\prime} \mathrm{E}$. This is confirmed by dives \#448 and \#449 which revealed that most of the eastern AVR of segment \#10 is buried by pillow fragments and basaltic talus [Fujimoto et al., 1999]. Again, smooth lava flows are only observed localized in the deep small basins around the AVRs of segment \#10. Faults, trending $\mathrm{E}-\mathrm{W}$, are more numerous than in segment \#11 suggesting that segment \#10 is in a more advanced tectonic stage [Mendel et al., 2003].

[12] The $82 \mathrm{~km}$-long section between $64^{\circ} 31^{\prime} \mathrm{E}$ and $65^{\circ} 20^{\prime} \mathrm{E}$ is characterized by the occurrence of extensive tectonized and/or sedimented terrains and by the absence of fresh-looking volcanic texture (Figures 4 and 8). Relict form of original extrusives are recognized in only very few restricted areas. No volcanic construction is observed over the small bathymetric swell which was interpreted as segment \#9 by Mendel et al. [1997] neither over the one located at $65^{\circ} 05^{\prime} \mathrm{E}$. Acoustic facies are complex and unusual over the entire axial valley width. Brightly backscattering zones characterized by a 


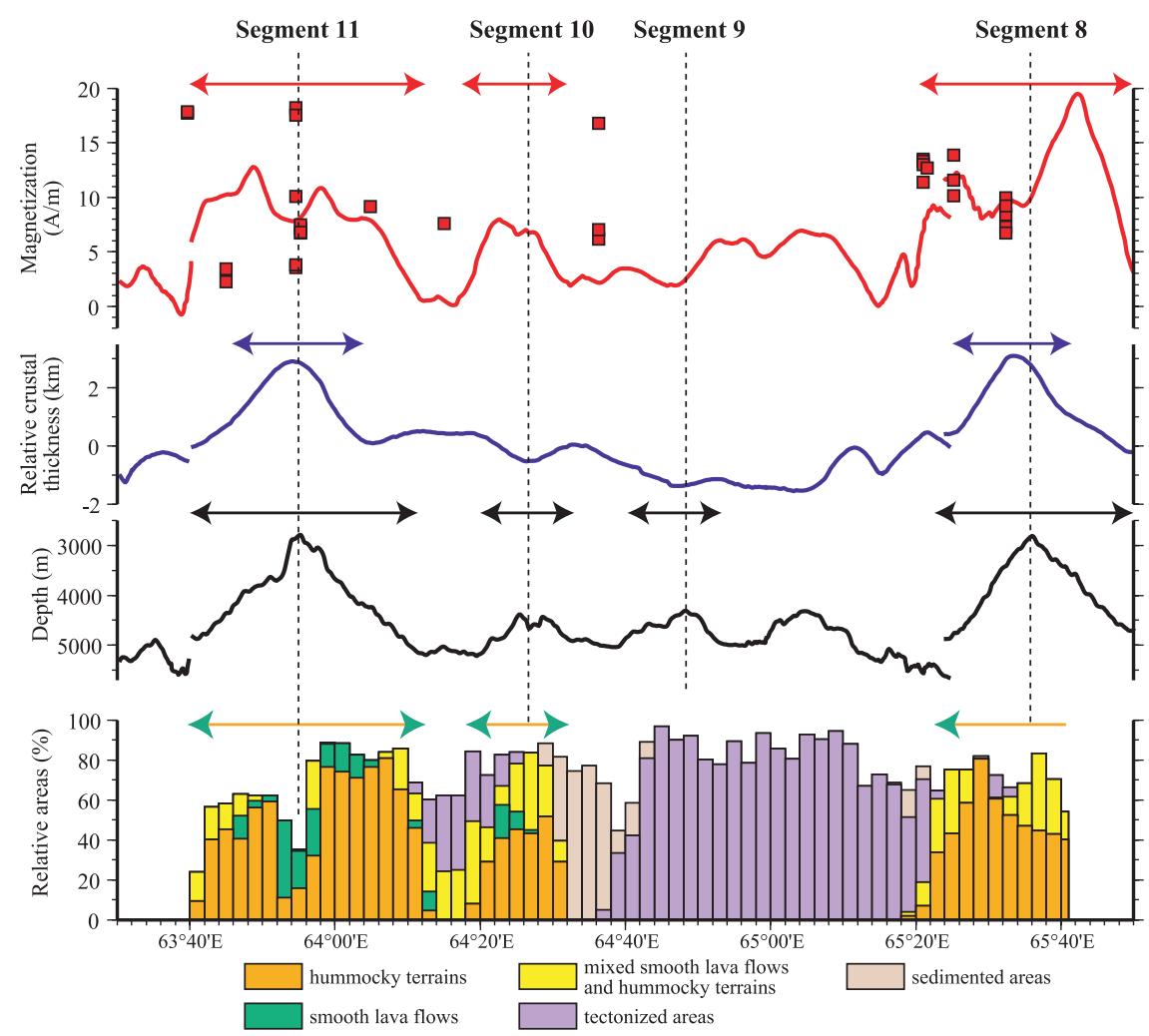

Figure 8. Along-axis distributions of hummocky texture, smooth lava flows, and tectonized areas compared to the segmentation in the survey area shown by the along-axis depth variation, relative gravity-derived crustal thickness after Cannat et al. [2003], and magnetization variation. Red squares indicate basalt magnetizations predicted using the chemistry of rift valley basalts [Meyzen et al., 2003] and the empirical relationship of Gee and Kent [1998] between FeO content and natural remanent magnetization of basalts. The relative area of each side scan sonar texture has been measured in $2^{\prime}$ wide NS striking strips superimposed to the texture map of Figure 4 . The proportions of seamounts, talus, scarps, and shadows are not shown. Arrows indicate the extent of the segments for each type of data.

linear fabric are interpreted as intensively faultdismembered older extrusive units (Figure 5c). Elsewhere, uniform medium to low backscatter surfaces suggest sediment cover (Figure 5e). The contact between the fresh-looking hummocks and the sedimented area at $64^{\circ} 31 \mathrm{E}$ (Figure 5e) is relatively sharp indicating a well defined age contrast between the volcanic ridge of segment \#10 and the sedimented marginal basin. We thus interpret this dismembered section with overall reduced backscatter amplitudes to be relatively older than the strongly reflective volcanic textures elsewhere. As the axial valley changes strike from $\mathrm{N} 95^{\circ} \mathrm{E}$ to $\mathrm{N} 60-65^{\circ} \mathrm{E}$, the population of faults in this section becomes more dispersed with orientations ranging from $\mathrm{N} 75^{\circ} \mathrm{E}$ to $\mathrm{N} 105^{\circ} \mathrm{E}$ (Figure 4).

[13] The most striking feature of the $5600 \mathrm{~m}$ deep basin to the west of the segment \#8 is the abundance of volcanic constructions (Figure 4). Hummocky textures are found interrupting the planar floor of the basin (Figure 5d). Backscatter amplitudes are generally low on the floor of the basin suggest- ing a draping of sediments and an implied greater age. A flat-topped seamount, $2.5 \mathrm{~km}$ in diameter with steep and strongly backscattering flanks and a small central depression, is located at the tip of the AVR of segment \#8. Fresh-looking hummocky terrain becomes predominant as the axial valley floor shallows toward the center of segment \#8. Smooth lava flows are restricted to the deep areas at the foot of the E-W trending AVR. The axial valley of segment $\# 8$, more oblique than that of segment \#11, is affected by only a few faults striking $\mathrm{N} 60-100^{\circ} \mathrm{E}$ (Figure 4). As to the west of the Melville FZ, this azimuthal distribution of the tectonic fabric in the oblique section of the ridge agrees well with the fault pattern obtained in laboratory experiments of oblique extension [Tron and Brun, 1991; Sauter et al., 2002].

\subsection{Axial Magnetization}

[14] The AVRs of segments \#11 and \#10 are characterized by about $8-13 \mathrm{~A} / \mathrm{m}$ higher magnetization values than the deeper tectonized area in- 
between (Figures 3c and 8). The along-axis decrease in magnetization from the segment central areas toward the deeper area between the two segments \#11 and \#10 mimics the decreasing abundance of volcanic terrains in this portion of the axial valley (Figure 8). In the $82 \mathrm{~km}$-long tectonized section between $64^{\circ} 31^{\prime} \mathrm{E}$ and $65^{\circ} 20^{\prime} \mathrm{E}$ our magnetization solution reveals that, contrary to the AVRs of segment \#11 and \#10, the small intrarift ridges of segment $\# 9$ do not correspond to high magnetization values (Figures $3 \mathrm{c}$ and 8 ). The highest magnetization values $(6-7 \mathrm{~A} / \mathrm{m})$ in this tectonized section are found on the bathymetric swell located at $65^{\circ} 05^{\prime} \mathrm{E}$ where among the smallest crustal thicknesses are observed (Figure 8). The AVR of segment \#8 is again characterized by about 20-13 $\mathrm{A} / \mathrm{m}$ higher magnetization values than the deep non-transform discontinuity to the west of this segment (Figure 8). As on segment \#11, the western edge of the volcanic terrains at $65^{\circ} 20^{\prime} \mathrm{E}$ corresponds to the extremity of the magnetic anomaly over segment \#8. Both elevated segments show also a marked low-magnetization anomaly at their centers similarly to those of the slowspreading Mid-Atlantic Ridge (Figure 8). The central magnetic anomaly is narrow and well defined over segments \#8, \#10 and \#11 (Figure 3c). By contrast, the section between segments \#9 and \#8 displays irregularly shaped anomalies with moderate to high magnetization level.

\section{Discussion}

[15] Seismic crustal thickness data acquired along the CAM116 profile show that, in addition to having a reduced crustal thickness $(\sim 3.7 \mathrm{~km}$ on average versus $\sim 6 \mathrm{~km}$ on the MAR), the easternmost SWIR at about $66^{\circ} \mathrm{E}$ shows significant variations in the crustal thickness of individual ridge segments [Muller et al., 1999]. The average seismic crustal thickness for the elevated segment \#8 (4.7 km) is larger than the average seismic crustal thickness along the CAM116 profile [Muller et al., 1999]. Similarly, the mean gravity-derived axial crustal thickness for the elevated segment \#11 (3.9 km) is also larger than the mean gravity-derived axial crustal thickness in the survey area $(2.9 \mathrm{~km})$ while the intervening low-relief segments $\# 10$ and $\# 9$ have gravityderived crustal thickness less than the reference $3 \mathrm{~km}$ used in the gravity model of Cannat et al. [2003]. These authors have thus suggested that there is a fundamental difference in the way melt is distributed along axis in the SWIR and the
MAR. Along the MAR, ridge segments appear to be supplied with the regional average amount of melt; along the SWIR, some elevated segments appear to receive more melt than the regional average while the intervening ridge segments appear to receive less. Our interpretation of the TOBI side scan sonar images of the SWIR axial valley shows that fresh-looking volcanic constructions occur on two elevated segments and that no fresh volcanism occurs along an intensely faulted $82 \mathrm{~km}$-long ridge section between them. This result supports thus the interpretation of the gravity data and argue for a strong focusing of the ridge melt supply beneath the elevated segments. The first part of the discussion summarizes the characteristics of melt focusing beneath the elevated segments and the distribution of melt to the intervening low-relief segments. We then discuss the presence of upper mantle rocks at the seafloor in the tectonized $82 \mathrm{~km}$-long section of the survey area. Finally, we address the question of the melt focusing mechanism in the easternmost part of the SWIR.

\subsection{Focused Magmatism}

[16] The strong correlation between high magnetization values, the distribution of fresh-looking volcanic terrains and the occurrence of AVRs crowning bathymetric swells at segments \#8, \#10 and \#11 (Figure 8) suggests that the magnetization variation outside the tectonized area is mainly related to variation in the thickness and/or the magnetization intensity of the extrusive lavas. Magnetizations decreasing from high values at the extremities of the AVRs to low values in the deeper axial discontinuities have been observed elsewhere along the SWIR [Dick et al., 2003; Hosford et al., 2003; Sauter et al., 2004]. More frequent eruptions along AVRs result in fresh volcanic seafloor and thicker extrusive lavas, whereas outside these AVRs, in the axial discontinuities, less frequent eruptions produce older, faulted and altered volcanic seafloor, such as between segments \#11 and \#10. Low magnetization values in such axial discontinuities could thus result from a thinner magnetic source layer due to fewer eruptions and/or reduced intensities from low-temperature oxidation of the extrusive basalts. Both elevated segments \#8 and \#11 display a marked low magnetization anomaly at their centers similarly to the segments of the slow-spreading MAR. Only one other segment (\#27 at $50^{\circ} 28^{\prime} \mathrm{E}$ ) among 10 studied along the SWIR by Sauter et al. [2004] shows such a marked low magnetization 


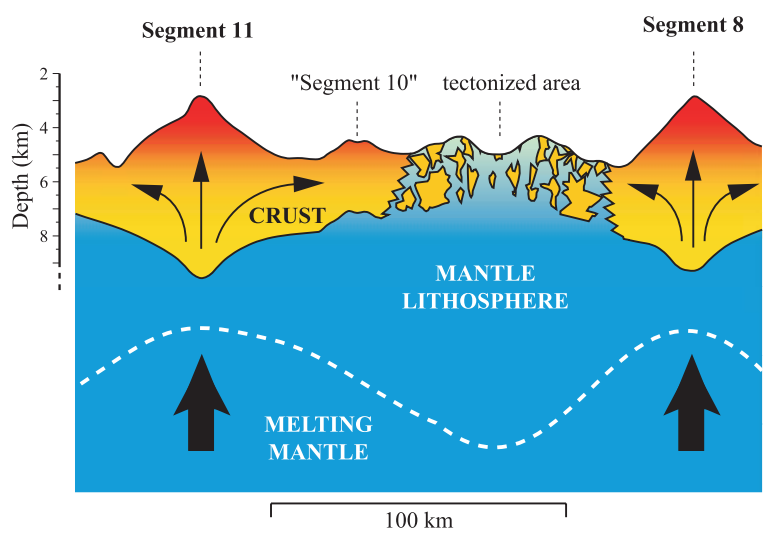

Figure 9. Schematic illustration for possible magmatic supply at the Southwest Indian Ridge between $63^{\circ} 30^{\prime} \mathrm{E}$ and $65^{\circ} 50^{\prime} \mathrm{E}$. Melt supply zones exist only beneath the magmatically robust segments \#11 and \#8. These segments correspond to $4.5-5 \mathrm{~km}$ thicker crust than the tectonized area observed on the TOBI side scan sonar images. The reddish colors along the axial valley floor indicate relatively fresh-looking volcanic terrains. No thicker crust is indicated by the gravity data beneath the low relief segment $\# 10$. We suggest that segment 10 is fed by crustal plumbing coming from the magmatically robust segment \#11. We also propose that the $82-\mathrm{km}$-long tectonized area corresponds to an area of very thin or missing crust where serpentinized peridotites are exposed at the seafloor. The thickness of the crust is derived from the gravity. The depth and shape of the lithosphere/ asthenosphere boundary are unconstrained.

anomaly at the segment center. Like segments \#8 and \#11, segment \#27 is an elevated segment where the axial valley disappears in the central part and corresponds to $3 \mathrm{~km}$ thicker crust than the adjacent axial discontinuities. Sauter et al. [2004] suggested that in contrast with the other SWIR segments, the magmatic activity at segment \#27 may be high enough for the lavas not to be highly fractionated. A higher rate of melt production may have created some form of reservoir where mixing of melts occurs and where crystalline fractionation is low producing low-magnetization lavas. By contrast, at other SWIR segments, magma chambers may be smaller resulting in restricted mixing and significant fractionation which may lead to relatively high intensity magnetization lavas. To determine whether such intrinsic magnetizations of the source layer may be responsible for the observed variations of the axial magnetization along segments \#8 and \#11, we used the chemistry of rift valley basalts [Meyzen et al., 2003] and the empirical relationship of Gee and Kent [1998] between $\mathrm{FeO}$ content and natural remanent magnetization of basalts. The predicted axial magnetizations agree remarkably well with magnetization amplitudes obtained by magnetic inversion along segment \#8 (Figure 8). However, the FeO content of fresh basaltic glasses is highly variable along segment \#11 and cannot be directly related to the observed axial magnetization variation at segment centers. Nevertheless, we propose that the correlation between the distribution of the volcanics, the magnetization and the occurrence of AVRs at segments \#8, \#10 and \#11 define a shallow segmentation of the ridge in the survey area related to the thickness and/or the intrinsic magnetization of the basaltic source layer.

[17] In contrast with this shallow segmentation, the strong along-axis variations of the gravity-derived crustal thickness only occur beneath the elevated segments \#8 and \#11 and are shrunken in length relative to the segmentation defined by the extrusive layer. The eastern end of segment \#11 is located at about $64^{\circ} 13^{\prime} \mathrm{E}$ and marked by both low magnetization values and a tectonized deep area whereas the edge of the thicker crust beneath segment \#11 is located $10 \mathrm{~km}$ closer to the segment center at $64^{\circ} 06^{\prime} \mathrm{E}$ (Figure 8). In the same way volcanic constructions are found up to $65^{\circ} 20^{\prime} \mathrm{E}$ in the deep basin adjacent to segment \#8 whereas the thicker crust corresponding to this segment is restricted to $65^{\circ} 26^{\prime} \mathrm{E}, 10 \mathrm{~km}$ closer to the segment center (Figure 8). Moreover, segments \#10 and $\# 9$ and the bathymetric swell located at $65^{\circ} 05^{\prime} \mathrm{E}$ do not correspond to thicker crust areas. We thus propose that the melt is highly focused beneath the magmatically robust segments \#11 and \#8 (Figure 9). A single melt supply zone occurs beneath each of these segments, feeding both the AVRs above and the volcanic terrain between these elevated segments by shallow lateral melt migration in the crust. We infer that this crustal plumbing is thus efficient up to $60 \mathrm{~km}$ from the center of segment \#11 and could feed the volcanic terrains corresponding to segment \#10 (Figure 9). Finally, we stress that segments \#11 and \#8 correspond to magmatically robust segments whereas segments $\# 10$ and $\# 9$ should not be classified as segments in a strict sense.

[18] On the flanks of the easternmost SWIR, a thick axial lithosphere is indicated by the high uncompensated elevations which are cut by large faults and dynamically maintained [Cannat et al., 2003]. The magma budget beneath the magmatically robust segments must therefore be high enough and its transport rapid enough so that only a small part of the melt crystallizes en route and that the remaining part of the magma is channeled 
through the axial lithosphere to build volcanic edifices at the seafloor. Rapid melt extraction through dikes rooting in deep melt-rich regions is the likely mechanism to transport the magma at the seafloor [Cannat et al., 1999]. As a large magma pressure is required to counteract the lithostatic pressure, the dikes may thus reach the seafloor and propagate tens of kilometers along axis. The abundance of smooth lava flows around the AVRs of the segments $\# 11, \# 10$ and $\# 8$ could result from such high magma pressure dike intrusions, since these lavas are generally emplaced with higher discharge rates than hummocky volcanic constructions [Perfit and Chadwick, 1998]. At the MAR, segment-tip magmatic propagation into regions of greater depth and thinner crust has been proposed to explain magmatic activity away from segment centers [Gràcia et al., 1997]. Smith and Cann [1999] suggest that a crustal magma reservoir provides magma to the rift axis through dikes and lava tubes that may propagate tens of kilometers along axis, inducing lengthening of volcanic ridges and eruptions in the axial discontinuity. As ageing, thickening and cooling lithosphere may inhibit shallow along-axis melt migration, the ridge obliquity probably controls the dike propagation processes. To the east of segment \#11, the ridge section is almost perpendicular to the spreading direction and the thermal perturbation associated with the small offsets of the axis may not be large enough to counteract the extensive along-axis melt distribution in the crust resulting in the occurrence of volcanic terrains in segment \#10 at distance up to $60 \mathrm{~km}$ from the center of segment \#11 (Figure 9). By contrast, the smaller westward extension of the volcanism around segment \#8 may result from the en echelon setting of the EW striking AVR of this segment in a more oblique ridge section. The western tip of this AVR abuts the northern axial valley wall which corresponds to a local stress barrier. Such effect of the ridge obliquity on accretion processes of ultra-slow spreading centers has already been noticed on the highly oblique southern Knipovich Ridge where it may also contribute to decreased effective spreading rates, lower upwelling magma velocity and melt formation [Okino et al., 2002].

\subsection{Amagmatic Spreading}

[19] Fresh-looking volcanic terrains are restricted over segments \#11, \#10 and \#8 and separated by sedimented and highly tectonized terrains which extend to a maximum along-axis length of $82 \mathrm{~km}$. Although such a long tectonized section has not been recognized at faster spreading ridges, an equivalent side scan sonar texture has been described by Parson et al. [2000] and Gràcia et al. [2000] on TOBI images of smaller non-transform offsets of the MAR (see their Figures $3 \mathrm{~g}$ and 3 , respectively). These MAR offsets display basement blocks which are commonly tectonized and in some cases completely dismembered. Some of these blocks have been examined and sampled, revealing that they are formed by upper mantle (serpentinites and peridotites) and lower crustal rocks (gabbros and dolerites) [Gràcia et al., 1997, 1999]. In the largest tectonized section of the TOBI survey area, the only available ground-truth data are provided by two dredges on the axial valley walls which both recovered serpentinized peridotites but no basalts (Figure 6) [Mével and EDUL Shipboard Scientific Party, 1997]. On the SWIR, serpentinized peridotites frequently crop out in the deepest part of the axis and therefore make up a significant portion of the lithosphere there [Mével and EDUL Shipboard Scientific Party, 1997; Seyler at al., 2003]. By contrast massive gabbros are not abundant suggesting that the composition of the upper lithosphere is mostly bimodal with volcanic and residual rocks [Mével et al., 1997]. Such a large amagmatic section has been described recently on the Gakkel ridge, another ultra-slow spreading ridge, where all extrusive volcanic activity along a 300-km-long amagmatic zone occurs in a $\sim 30 \mathrm{~km}$ stretch of the axis whereas large exposure of mantle peridotites are found in the rest of the zone [Cochran et al., 2003; Michael et al., 2003]. Long amagmatic accretionary ridge segments, quite distinct from what is observed at the MAR, appear thus to become characteristic of ultra-slow spreading ridges [Dick et al., 2003].

[20] Up to now, the observed amagmatic sections and axial discontinuities of ultra-slow spreading ridges were characterized by weak magnetization relative to the segments [Sauter et al., 2001; Dick et al., 2003]. By contrast, on the fasterspreading MAR, the amplitude of the axial magnetic anomaly and equivalent magnetization increase at segment ends at various locations [e.g., Ravilly et al., 1998]. Such higher magnetization values at segment ends at both the axis and on the flanks of the MAR were attributed to a combination of crustal thinning and alteration of lower crust and upper mantle at segment ends [e.g., Tivey and Tucholke, 1998]. The magnetic 
contribution of upper mantle rocks may indeed become significant $(4-10 \mathrm{~A} / \mathrm{m}$ on average) when the amount of magnetite increases rapidly for high degree of serpentinization (>75\%) [Oufi et al., 2002]. However, as no high magnetization anomaly has previously been observed in the amagmatic sections of the SWIR, along-axis variation of magnetization has been solely attributed to the thickness and intrinsic magnetization variations of the extrusive lavas [Sauter et al., 2004]. The serpentinization of peridotites was thought to have no significant contribution at the axis but, off-axis, upper mantle rocks may become progressively more altered producing the disappearance of the magnetic reversal pattern and the increase of the magnetization observed along the traces of the large axial discontinuities regardless of polarity [Sauter et al., 2004]. In the TOBI survey area, in contrast with other amagmatic sections of ultra-slow spreading ridges, a small moderate magnetization anomaly $(\sim 7 \mathrm{~A} / \mathrm{m})$ is observed in the central part of the tectonized amagmatic section where the crust is dramatically thin. As the thin carapace of basalts, if any in this amagmatic section, is strongly faulted and altered with natural remanent magnetization intensity quickly decreasing with increasing age [e.g., Zhou et al., 2001], this magnetization anomaly probably not results from a basaltic source layer but might rather be related to the underlying mantle lithosphere. The absence of thick crust and the strong faulting may indeed facilitate the penetration of seawater down to the upper mantle rocks resulting in their weathering and an increase of their magnetization. We thus propose that the small magnetization anomaly in the $82 \mathrm{~km}$-long tectonized section may result from a prolonged chemical magnetization which is acquired during the serpentinization of peridotites. The uniqueness of the magnetization increase in the tectonized section of the TOBI survey area relative to the other amagmatic sections of ultra-slow spreading ridges is probably related to the combination of both a regional anomalously low volume of melt in the easternmost part of the SWIR and the presence of a significantly thin crust in a very large amagmatic section between two segments. In these other amagmatic sections, the crust may be thick enough so that the serpentinization process may be delayed by the shielding effect of the crust. For example, beneath the smaller tectonized area between segment \#11 and \#10 where seawater has to cross $\sim 2 \mathrm{~km}$ thicker crust before reaching the upper mantle, the serpentinization process may be less intense producing no moderate magnetization anomaly but weak magnetization values relative to the segment centers. Serpentinization of peridotites has already been put forward by Sichler and Hékinian [2002] on a comparable amagmatic ridge section of the MAR. These authors explain a wider central magnetic anomaly than that expected by the Nuvel-1 kinematic model by such a weathering process in a magmatically starved ridge section of the equatorial MAR which is thought to be related to a thermal minima in the upper mantle [Bonatti, 1996]. A comprehensive study of the amplitude and width of the axial magnetic anomaly along the whole SWIR could constrain the question of the magnetic contribution of serpentinized peridotites and test the hypothesis of a shielding effect of the crust. Further seismic studies are also needed to determine the crustal structure along the segments and the amagmatic sections of the easternmost SWIR.

\subsection{Segmentation}

[21] In our survey area, melt that reaches the seafloor is erupted at distinct locations along the axis separated by long sections where magmatic activity is absent or at least highly reduced. To explain this segmentation one may argue that the greatly reduced amount of melt produced by decompression melting at extremely low spreading rates [Reid and Jackson, 1981; Bown and White, 1994] may be insufficient to maintain magmatic spreading along the whole axis. However, by contrast to the easternmost SWIR where strong melt focusing occurs for at least the past 10 Myr [Cannat et al., 2003], other parts of the SWIR do not display the same segmentation although the spreading rate is almost the same. This indicates that factors in addition to spreading rate play a role in determining magmatic vigor along the ridge. The segmentation of the SWIR to the east of the Melville FZ occurs also in the absence of large offsets of the axis indicating that the ridge segmentation is mainly controlled by processes of magmatic segregation in the upper mantle and does not require a tectonic segmentation imposed by the lithosphere. Mantle source heterogeneities together with lower mantle temperatures beneath the easternmost SWIR [Meyzen et al., 2003; Seyler et al., 2003] could partly control its segmentation. Such explanation has been suggested by Cochran et al. [2003] and Michael et al. [2003] to explain the paucity of magmatism along the Gakkel ridge 
between $3^{\circ} \mathrm{E}$ and $29^{\circ} \mathrm{E}$. Early melting of a passively imbedded chemical heterogeneity in the mantle may indeed encourage inflow and focusing of melt over the inhomogeneity [Michael et al., 1994]. Strong and transient melt-focusing events could then be initiated by a localized increase in the volume of melt supplied by the melting mantle to the base of the axial lithosphere, causing thermal thinning of this lithosphere and melt migration [Cannat et al., 2003]. These two mechanisms may combine to effectively focus large volumes of melt toward the center of thick crust segments of the SWIR to the east of the Melville FZ.

\section{Conclusions}

[22] The analysis of the TOBI images along the Southwest Indian Ridge between $63^{\circ} 40^{\prime} \mathrm{E}$ and $65^{\circ} 40^{\prime} \mathrm{E}$ and their comparison with along-axis gravity-derived crustal thickness and magnetization variations suggest the following conclusions:

[23] 1. Fresh-looking volcanic terrains are observed at distinct locations along the axis separated by highly tectonized and sedimented terrains whose along-axis dimension reaches up to $82 \mathrm{~km}$. The largest tectonized section corresponds to a dramatically thin crust area with moderate magnetization anomalies. We suggest that seafloor spreading is mainly amagmatic in this tectonized section of the SWIR with upper mantle rocks exposed at the seafloor. Such long amagmatic accretionary ridge segments, quite distinct from what is observed at the MAR, appear thus to become characteristic of ultra-slow spreading ridges.

[24] 2. The correlation between high magnetization values, the distribution of fresh-looking volcanic terrains and the occurrence of axial volcanic ridges suggests a shallow segmentation of the ridge mainly related to variation in the thickness and/or the intrinsic magnetization of the basaltic source layer.

[25] 3. Strong, along-axis variations of the gravityderived crustal thickness only occur beneath elevated segments and are shrunken in length relative to the shallow segmentation of the ridge. Some small bathymetric swells crowned by AVRs with fresh-looking volcanic constructions do not correspond to thicker crust areas. This suggests highly focused melt supply beneath the elevated segments which may feed the volcanic constructions up to $60 \mathrm{~km}$ from the center of these segments by shallow lateral melt migration in the crust, probably through dikes.

[26] 4. Neither the ultra-slow spreading rate, nor the ridge obliquity, explains the variations of the magmatic vigor along the ridge. Mantle source heterogeneities together with lower mantle temperatures beneath the easternmost SWIR could partly control its segmentation.

\section{Acknowledgments}

[27] We are indebted to the members of the FUJI Scientific Team: Philippe Blondel, Daniel Boulanger, Alan Evans, Chris German, Olga Gomez, Sang-Mook Lee, Yukihito Osada, Philippe Patriat, Gaud Pouliquen, Roger Searle, Chiori Tamura, Tomoaki Yamada, and Tomohiro Yama-ashi. We thank Yvon Balut and Commandant Patrick Regnier, officers, and crew of the R/V Marion Dufresne for their assistance during the FUJI cruise. We want to thank Bernard Olivier for $24 \mathrm{~h} /$ day technical assistance, and Christopher Flewellen, Robert Wallace, and Duncan Matthews for running the TOBI. Figures were created using the public domain GMT software [Wessel and Smith, 1995]. Ship time was cofunded by Japan and France, and the TOBI operations were supported by the European Community through an EASSS program. Participation to the cruise and postcruise studies were supported by the Centre National de la Recherche Scientifique (CNRS-INSU), the University of Durham, and the Natural Environment Research Council (NERC). This is EOST contribution 2004.08-UMR7516.

\section{References}

Blondel, P., and B. Murton (1997), Handbook of Seafloor Sonar Imagery, Wiley-Praxis Series in Remote Sensing, 314 pp., John Wiley, New York.

Bonatti, E. (1996), Long-lived oceanic transform boundaries formed above mantle thermal minima, Geology, 24, 803806.

Bown, J. W., and R. S. White (1994), Variation with spreading rate of oceanic crustal thickness and geochemistry, Earth Planet. Sci. Lett., 121, 435-449.

Cannat, M., C. Rommevaux-Jestin, D. Sauter, C. Deplus, and V. Mendel (1999), Formation of the axial relief at the very slow spreading Southwest Indian Ridge $\left(49^{\circ}\right.$ to $\left.69^{\circ} \mathrm{E}\right)$, J. Geophys. Res., 104, 2825-2843.

Cannat, M., C. Rommevaux-Jestin, and H. Fujimoto (2003), Melt supply variations to a magma-poor ultra-slow spreading ridge (Southwest Indian Ridge $61^{\circ}$ to $69^{\circ} \mathrm{E}$ ), Geochem. Geophys. Geosyst., 4, 9104, doi:10.1029/2002GC000480.

Cannat, M., D. Sauter, V. Mendel, E. Ruellan, K. Okino, E. Humler, V. Combier, and M. Baala (2004), A >26 Myrs record of melt supply variations and axial tectonics in a magma-poor region of the very slow spreading Southwest Indian Ridge, paper presented at Goldschmidt Conference 2004, Univ. of Copenhagen, Copenhagen, 5-11 June.

Cochran, J. R., G. J. Kurras, M. H. Edwards, and B. J. Coakley (2003), The Gakkel Ridge: Bathymetry, gravity anomalies, and crustal accretion at extremely slow spreading rates, J. Geophys. Res., 108(B2), 2116, doi:10.1029/ 2002JB001830. 
Debayle, E., and J.-J. Lévêque (1997), Upper mantle heterogeneities in the Indian Ocean from waveform inversions, Geophys. Res. Lett., 24, 245-248.

DeMets, C., R. G. Gordon, D. F. Argus, and S. Stein (1990), Current plate motions, Geophys. J. Int., 101, 425-478.

Dick, H. J. B., J. Lin, and H. Schouten (2003), An ultraslow-spreading class of ocean ridge, Nature, 426, 405412 .

Flewellen, C. G., N. W. Millard, and I. P. Rouse (1993), TOBI, a vehicle for deep ocean survey, J. Electron. Commun. Eng., $5,85-93$.

Fujimoto, H., and MODE'98 Leg3 Shipboard Scientific Party (1998), INDOYO Onboard Cruise Report, 346 pp., Jpn. Mar. Sci. and Technol. Cent., Tokyo.

Fujimoto, H., et al. (1999), First submersible investigations of mid-ocean ridges in the Indian Ocean, InterRidge News, $8(1), 22-24$.

Gee, J., and D. V. Kent (1998), Magnetic telechemistry and magmatic segmentation on the southern East Pacific Rise, Earth Planet. Sci. Lett., 164, 379-385.

Gràcia, E., D. Bideau, R. Hékinian, Y. Lagabrielle, and L. M. Parson (1997), Along-axis magmatic oscillations and exposures of ultramafic rocks in a second-order segment of the Mid-Atlantic Ridge $\left(33^{\circ} 43^{\prime} \mathrm{N}\right.$ to $\left.34^{\circ} 07^{\prime} \mathrm{N}\right)$, Geology, 25, 1059-1062.

Gràcia, E., D. Bideau, R. Hékinian, and Y. Lagabrielle (1999), Detailed geological mapping of two contrasting second-order segments of the Mid-Atlantic Ridge between Oceanographer and Hates fracture zones $\left(33^{\circ} 30^{\prime} \mathrm{N}-35^{\circ} \mathrm{N}\right)$, J. Geophys. Res., $104,22,903-22,921$.

Gràcia, E., J. L. Charlou, J. Radford-Knoery, and L. M. Parson (2000), Non-transform offsets along the Mid-Atlantic Ridge south of the Azores $\left(38^{\circ} \mathrm{N}-34^{\circ} \mathrm{N}\right)$ : Ultramafic exposures and hosting of hydrothermal vents, Earth Planet. Sci. Lett., 177, 89-103.

Hosford, A., M. Tivey, T. Matsumoto, H. Dick, H. Schouten, and H. Kinoshita (2003), Crustal magnetization and accretion at the Southwest Indian Ridge near the Atlantis II fracture zone, 0-25 Ma, J. Geophys. Res., 108(B3), 2169, doi:10.1029/2001JB000604.

Kuo, B. Y., and D. W. Forsyth (1988), Gravity anomalies of the ridge transform system in the South Atlantic between $31^{\circ}$ and $34.5^{\circ} \mathrm{S}$ : Upwelling centers and variation in crustal thickness, Mar. Geophys. Res., 10, 205-232.

Lawson, K., R. C. Searle, J. A. Pearce, P. Browning, and P. Kempton (1996), Detailed volcanic geology of the MARNOK area, Mid-Atlantic Ridge north of Kane transform, Geol. Soc. Spec. Publ., 118, 61-102.

Macdonald, K. C., S. P. Miller, S. P. Huestis, and F. N. Spiess (1980), Three-dimensional modeling of a magnetic reversal boundary from inversion of deep-tow measurements, J. Geophys. Res., 85, 3670-3680.

Mendel, V., D. Sauter, L. Parson, and J.-R. Vanney (1997), Segmentation and morphotectonic variations along a super slow-spreading center: The Southwest Indian Ridge $\left(57^{\circ} \mathrm{E}-\right.$ $\left.70^{\circ} \mathrm{E}\right)$, Mar. Geophys. Res., 19, 505-533.

Mendel, V., D. Sauter, C. Rommevaux-Jestin, P. Patriat, F. Lefebvre, and L. M. Parson (2003), Magmato-tectonic cyclicity at the ultra-slow spreading Southwest Indian Ridge: Evidence from variations of axial volcanic ridge morphology and abyssal hills pattern, Geochem. Geophys. Geosyst., 4, 9102, doi:10.1029/2002GC000417.

Mével, C., and EDUL Shipboard Scientific Party (1997), EDUL cruise report, R/V Marion Dufresne 107, 184 pp., Lab. de Pétrol., Univ. Paris VI, Paris.
Mével, C., et al. (1997), Sampling the Southwest Indian Ridge: First results of the EDUL cruise (R/V Marion Dufresne II, August 1997), InterRidge News, 6(2), 25-26.

Meyzen, C. M., M. J. Toplis, E. Humler, J. N. Ludden, and C. Mével (2003), A major discontinuity in mantle composition beneath the Southwest Indian Ridge, Nature, 421, 731733.

Michael, P. J., and W. C. Cornell (1998), Influence of spreading rate and magma supply on crystallization and assimilation beneath mid-ocean ridges: Evidence from chlorine and major element chemistry of mid-ocean ridge basalts, $J$. Geophys. Res., 103, 18,325-18,356.

Michael, P. J., et al. (1994), Mantle control of a dynamically evolving spreading center: Mid-Atlantic Ridge $31-34^{\circ} \mathrm{S}$, Earth Planet. Sci. Lett., 121, 451-468.

Michael, P. J., et al. (2003), Magmatic and amagmatic seafloor generation at the ultraslow-spreading Gakkel Ridge, Arctic Ocean, Nature, 463, 956-961.

Mitchell, N. C. (1993), A model for attenuation of backscatter due to sediment accumulations and its application to determine sediment thicknesses with GLORIA sidescan sonar, J. Geophys. Res., 98, 2477-2493.

Mitchell, N. C., R. A. Livermore, P. Fabretti, and G. Carrara (2000), The Bouvet triple junction, 20 to $10 \mathrm{Ma}$, and extensive transtensional deformation adjacent to the Bouvet and Conrad transforms, J. Geophys. Res., 105, 8279-8296.

Muller, M. R., T. A. Minshull, and R. S. White (1999), Segmentation and melt supply on the Southwest Indian Ridge, Geology, 27, 867-870.

Münch, U., C. Lalou, P. Halbach, and H. Fujimoto (2001), Relict hydrothermal events along the super slow southwest Indian spreading ridge near $63^{\circ} 56^{\prime} \mathrm{E}$ - Mineralogy, chemistry and chronology of sulfide samples, Chem. Geol., 177, 341349.

Okino, K., D. Curewitz, M. Asada, K. Tamaki, P. Vogt, and K. Crane (2002), Preliminary analysis of the Knipovich ridge segmentation: Influence of focused magmatism and ridge obliquity on an ultraslow spreading system, Earth Planet. Sci. Lett., 6319, 1-14.

Oufi, O., M. Cannat, and H. Horen (2002), Magnetic properties of variably serpentinized abyssal peridotites, J. Geophys. Res., 107(B5), 2095, doi:10.1029/2001JB000549.

Parker, R. L., and S. P. Huestis (1974), The inversion of magnetic anomalies in the presence of topography, J. Geophys. Res., 79, 1587-1593.

Parson, L. M., E. Gràcia, D. Coller, C. German, and D. Needham (2000), Second-order segmentation: The relationship between volcanism and tectonism at the MAR, $38^{\circ} \mathrm{N}-35^{\circ} 40^{\prime} \mathrm{N}$, Earth Planet. Sci. Lett., 178, 231-251.

Patriat, P., and J. Segoufin (1988), Reconstruction of the Central Indian Ocean, Tectonophysics, 155, 211-234.

Patriat, P., D. Sauter, M. Munschy, and L. Parson (1997), A survey of the Southwest Indian Ridge axis between Atlantis II FZ and the Indian Ocean Triple Junction: Regional setting and large scale segmentation, Mar. Geophys. Res., 19, 457480.

Perfit, M. R., and W. W. Chadwick Jr. (1998), Magmatism at mid-ocean ridges: Constraints from volcanological and geochemical investigations, in Faulting and Magmatism at Mid-ocean Ridges, Geophys. Monogr. Ser., vol. 106, edited by W. R. Buck et al., pp. 59-115, AGU, Washington, D. C.

Ravilly, M., J. Dyment, P. Gente, and R. Thibaud (1998), Axial magnetic anomaly amplitude along the Mid-Atlantic Ridge between $20^{\circ} \mathrm{N}$ and $40^{\circ} \mathrm{N}, J$. Geophys. Res., 103, 24,20124,222 . 
Reid, I., and H. R. Jackson (1981), Oceanic spreading rate and crustal thickness, Mar. Geophys. Res., 5, 165-172.

Rommevaux, C., C. Deplus, and P. Patriat (1994), Threedimensional gravity study of the Mid- Atlantic Ridge: Evolution of the segmentation between $28^{\circ}$ and $29^{\circ} \mathrm{N}$ during the last 10 m.y., J. Geophys. Res., 99, 3015-3029.

Rommevaux-Jestin, C., C. Deplus, and P. Patriat (1997), Mantle Bouguer Anomaly along a super-slow spreading ridge: Comparison with the central Mid-Atlantic Ridge and implications on the accretionary process, Mar. Geophys. Res., 19, 479-501.

Sauter, D., P. Patriat, C. Rommevaux-Jestin, M. Cannat, A. Briais, and Gallieni Shipboard Scientific Party (2001), The Southwest Indian Ridge between $49^{\circ} 15^{\prime} \mathrm{E}$ and $57^{\circ} \mathrm{E}$ : Focused accretion and magma redistribution, Earth Planet. Sci. Lett., 192, 303-317.

Sauter, D., L. Parson, V. Mendel, C. Rommevaux-Jestin, O. Gomez, A. Briais, C. Mével, K. Tamaki, and the FUJI Scientific Team (2002), TOBI sidescan sonar imagery of the very slow-spreading Southwest Indian Ridge: Evidence for along-axis magma distribution, Earth Planet. Sci. Lett., 199, $81-95$.

Sauter, D., H. Carton, V. Mendel, M. Munschy, C. RommevauxJestin, J.-J. Schott, and H. Whitechurch (2004), Ridge segmentation and the magnetic structure of the Southwest Indian Ridge (at $50^{\circ} 30^{\prime} \mathrm{E}, 55^{\circ} 30^{\prime} \mathrm{E}$ and $66^{\circ} 20^{\prime} \mathrm{E}$ ): Implications for magmatic processes at ultraslow-spreading centers, Geochem. Geophys. Geosyst., 5, Q05K08, doi:10.1029/2003GC000581.

Seyler, M., M. Cannat, and C. Mével (2003), Evidence for major-element heterogeneity in the mantle source of abyssal peridotites from the Southwest Indian Ridge $\left(52^{\circ}\right.$ to $\left.68^{\circ} \mathrm{E}\right)$, Geochem. Geophys. Geosyst., 4, 9101, doi:10.1029/ 2002GC000305.

Sichler, B., and R. Hékinian (2002), Three-dimensional inversion of marine magnetic anomalies on the equatorial Atlantic Ridge (St. Paul Fracture Zone): Delayed magnetization in a magmatically starved spreading center?, J. Geophys. Res., 107(B12), 2347, doi:10.1029/2001JB000401.

Smith, D. K., and J. R. Cann (1999), Constructing the upper crust of the Mid-Atlantic Ridge: A reinterpretation based on the Puna ridge, Kilauea volcano, J. Geophys. Res., 104, $25,379-25,399$.

Smith, W. H. F., and D. T. Sandwell (1995), Marine gravity field from declassified Geosat and ERS-1 altimetry, Eos Trans. $A G U, 76,156$

Tamaki, K., C. Mével, and the FUJI Scientific Party (1998), Spreading tectonics of the eastern part of the Southwestern Indian Ridge: A synthesis of FUJI expedition (abstract), Eos Trans. $A G U, 79,892$.

Tivey, M. A., and B. E. Tucholke (1998), Magnetization of 0$29 \mathrm{Ma}$ ocean crust on the Mid-Atlantic ridge, $25^{\circ} 30$ to $27^{\circ} 10^{\prime} \mathrm{N}$, J. Geophys. Res., 103, 17,807-17,826.

Tron, V., and J. P. Brun (1991), Experiments on oblique rifting in brittle-ductile systemsTectonophysics, 188, 71-84.

Wessel, P., and W. H. F. Smith (1995), New version of Generic Mapping Tools released, Eos Trans. AGU, 76, 329.

Zhou, W., R. Van der Voo, D. R. Peacor, D. Wang, and Y. Zhang (2001), Low-temperature oxidation in MORB of titanomagnetite and titanomaghemite: A gradual process with implications for marine magnetic anomaly amplitudes, J. Geophys. Res., 106(B4), 6409-6421. 